\title{
Do more mergers and acquisitions create value for shareholders?
}

\begin{abstract}
How does an investor value the announcement of new business integration? The history of acquirer's acquisition may matter for investors. Existing research are divided to the positive or negative answer to the question. Based on the global evidence of 24,263 acquisitions across 81 countries over 19 years, this paper argues that the current contradictory views have failed to take into account the time interval between acquisitions. This is because the wavelength of merger frequency can change the investors' expectations of new business integration and so investment returns. With control of the time interval of a new merger we discover that more mergers generate lower abnormal returns. This finding extends our understanding of the value perception of investors on a merger announcement that can be affected not only by merger numbers but also by their time distribution.
\end{abstract}

JEL classification: 14, G34

Keywords: Merger and acquisition; Frequent acquisitions; Abnormal return; Learning; Hubris 


\section{Introduction}

The vast majority of research on mergers and acquisitions assumes mergers and acquisitions (henceforth, M\&A) are singular firm events. However, rather than making an acquisition occasionally, acquirers frequently conduct streams of mutual interrelated M\&A to fulfill their strategic goals for enhanced value or performance. Examples of this can be witnessed with Cisco, General Electric, Google, and Facebook (Ang et al. 2018; Laamanen and Keil 2008). The field of frequent M\&A research, of which recurrent acquirers form a part, has generated considerable knowledge and shown important facts about impacts of this phenomenon (See for example, Aktas et al. 2011; Arikan and Stulz 2016; Castellaneta and Conti 2017; Chao 2018; Degbey 2015; Fuller et al. 2002; Gong et al. 2019).

Schipper and Thompson (1983) emphasize the repetitive nature of acquisitions and report that a series of M\&A announcements can create value. However, existing studies find declining Cumulative Abnormal Returns (CARs) during serial M\&A. This suggests that market reactions to subsequent deal announcements do not represent the full value created but instead are revisions of previous investor anticipations (Conn et al. 2005; Fuller et al. 2002). One of the streams of research noted a commonly reported fact, namely, that subsequent M\&A will decrease the value of the acquirers' CARs during engagement of serial M\&A (Conn et al. 2005; Croci and Petmezas 2009; Fuller et al. 2002; Ismail 2008). This persists even after controlling for CEO effects (Billett and Qian 2008). One possible explanation for this is the occurrence of managerial hubris on management decisions (Roll 1986), suggesting that that hubris- infected managers of acquiring firms value the target higher than the market valuation. This may cause them to pay a higher premium to acquire the target (Amor and Kooli 2016; Ismail and Abdallah 2013; Malmendier and Tate 2008; Moeller et al. 2004; Shih and Hsu 2009).

Declining values attributed with M\&A are also consistent with several other explanations which are theoretically compatible with a negative impact on the M\&A performance of acquiring firms. 
Corporate governance research employs the concept mainly in the context of conflicts in strategic decisions (e.g. Aktas et al. 2016). Such literature highlights the 'control' perspective in governance, anchored in agency theory (Jensen 1986). The declining acquisition gains tend to be associated with the conflict of interest as these managers have opportunities to increase their personal wealth or to further their careers and reputations rather than firm profits (Chang et al. 2018). With the agency problem, it is expected that the efficiency of investment would diminish with more frequent mergers and takeovers (Schipper and Thompson 1983). Klasa and Stegemoller (2007) provide the third explanation of "time-varying investment opportunity sets" which predicts that the best targets are acquired first and worse targets at a future date. More specifically, this hypothesis predicts that serial acquisitions can establish a positive value, while the return declines as the number of M\&A rise. Given that the serial M\&A is driven by investment opportunity, there should be no correlation between past M\&A performance and the likelihood of future deals (Billett and Qian 2008). Furthermore, market timing is another motive that can result in value decreasing M\&As, suggesting that rational acquirers understand misevaluation in inefficient financial markets and therefore time the market to take advantage of it (Chuang 2018; Dong et al. 2006).

There is a strand of evidence which displays positive impact of serial M\&A as they offer various advantages such as efficiency gains (Avkiran 1999) and the immediate access to external resources (Al-Laham et al. 2010; Heeley et al. 2006; Nam et al. 2005). However, this line of reasoning is inconclusive as M\&A involves causal ambiguity. Organizational learning impact during serial M\&A is theoretically compatible with increasing abnormal returns from deal to deal in most studies (e.g. Ashkenas et al. 1997; Barkema et al. 1996; Bruton et al. 1994; Degbey 2015; Fowler and Schmidt 1989; Harford and Schonlau 2013; Hayward 2002; Hitt et al. 1998; Humphery-Jenner 2014; Kusewitt 1985; Nadolska and Barkema 2014; Trichterborn et al. 2015). The repetition of M\&A tasks over time leads to some learning and therefore to improved performance (Field and Mkrtchyan 2017). Rather than offering learning explanation on the firm level, a line of research has identified the quality of acquisition experience such as the similarity of experience by industry or country. Scholars suggest 
that prior industry-specific M\&A experience results in the development and refinement of routines that facilitate subsequent deals in the same industry (Basuil and Datta 2015). This can make the industry more concentrated enhancing the market power of the firm in setting higher prices for more profits (Kamien and Zang 1993).

Drawing on organizational learning theory, scholars provide evidence of the concept of "near transfers' (Perkins and Salomon 1992) and argue that inferences from similar experience enhance subsequent performance (Basuil and Datta 2015). In the director marketplace acquisition experience is valued (Harford and Schonlau 2013). For instance, Castellaneta and Conti (2017) using a sample of 1388 US M\&A executed over the period 1975-2005 on the role of M\&A learning, indicate moreexperienced acquirers will perform particularly well as acquisition experience translates more readily into learning when the information environment in which the ability to select is more important.

Engagement in market timing may also positively affect acquirer's performance when sequentially making acquisitions. The market timing theory is a direct contradiction to Roll (1986)'s hubris hypothesis, based on the opposite assumption. This is because financial markets are considered to be irrational, while bidder managers are rational in making their merger decisions (Antoniou and Zhao 2007). It suggests that acquisitions will be caused by realizations of the incorrect valuations by acquirers (Rhodes - Kropf and Viswanathan 2004). For instance, when chosen targets are less overvalued than the acquirer or undervalued, acquirers profit either by paying stock for less overvalued targets or by buying undervalued targets (relative to target fundamental values) for cash at a price below its underlying value (Dong et al. 2006; Shleifer and Vishny 2003; Vermaelen and Xu 2014).

As such, rational acquirers are likely to co-move with market timing factors because they understand misevaluation in the inefficient financial markets. This enables them to take advantage, gaining positive returns during serial acquisitions even if no synergies are involved (e.g. Dong et al. 2006; Savor and Lu 2009). Furthermore, technological synergy is another possible explanation of 
positive market reaction for serial acquisition (Bena and Li 2014; Lin and Wang 2016). In this situation the acquisitions of targets with implicit knowledge are more likely to receive favorable market reaction and increasing stock returns (Canace and Mann 2014). This is because the strengthened innovation prowess (e.g. expanded and less-time spent in-house innovations and improved technological competencies) and more competitive positioning in the market associated with technological acquisitions, leave a firm more vulnerable to technological shocks. There is also a lower probability of being shocked by unanticipated entrants with emerging technologies (Cassiman and Veugelers 2006; Humphery-Jenner 2014).

As we have seen from the above evidence, existing studies are controversial about the impact of serial M\&A. The concept that more M\&A can make higher CARs is still a puzzling phenomenon (Faff et al. 2019). This paper examines this question from the perspective of a stock market's expectation of a firm that acquires a new business. Fuller et al. (2002) mention that a stock market reacts to the announcement of an acquisition of a new business differently according to if the firm is a frequent acquirer or not. This is because frequent acquirers are able to release more information about their own characteristics to the public due to repetitive corporate activities in the market. The released information is helpful to the stock market, enabling perceived or expected future stock returns that can be improved by the acquiring firm.

This study focuses on assessment of merger frequency from the perspective of how stock investors perceive the value creation of serial M\&A. If the announcement of new acquisition is positively perceived by investors, then the CARs for the acquiring firm will rise at least in the short run. We examine the CARs or investment returns on the announcement globally, which is distinctive from prior research that rely on country-focused sample data. Our large sample has been collected from different countries and includes 9500 public acquirers that pursued 24263 takeovers during the period $1^{\text {st }}$ January 2000 to $31^{\text {st }}$ December 2018. Among these acquirers, 4862 carried out more than one acquisition across the sample span. 
In order to study the impact of merger frequency on investment returns, a key challenge is how to define a firm's 'frequency' in acquiring new businesses. In our study, the merger frequency is defined as the number of acquisitions undertaken by an acquirer during a specific time horizon. Given this definition, acquiring firms are classified according to infrequent, frequent and highly frequent acquisitions. Infrequent acquisition is regarded as an acquiring firm that has acquired only one new business over the sample period from 2000 to 2018. In contrast, frequent acquisition is specified as an acquirer that has pursued two to four acquisitions of new business over the sample period of time, and highly frequent acquisition is regarded as an acquirer that has tracked five or more acquisitions during the sample period of time.

With three groups of merger frequency, we are able to compare CARs of the acquiring firms among three different frequencies in one day surrounding the announcement time. To make our comparison more rigorous and distinctive from existing studies, we also take into account the factor of the time interval between two acquisitions and how it affects investors' perception of a new acquisition. The expectation of the interval effect is given the same frequency, the longer the interval between the new acquisition and the previous one, the greater the performance of the acquiring firm. This is due to management gaining more time to digest opportunities and challenges brought by the integration of new business. This in turn enables the firm to be in a healthier position when preparing another new acquisition.

Overall, one major finding from our global sample data shows that lack of control on the time interval effect supports the expectation of the management hubris, which can cause a negative perception of merger frequency from investors. For investment returns of announcement, we found that the infrequent group outperforms the frequent group, and the frequent outperforms the highly frequent. CARs diminish in subsequent deals. In particular, the diminishing pattern is more clearly noticeable for firms with a higher frequency of acquisitions. 
Furthermore, when we compare different time intervals for mergers with a similar frequency an interesting pattern of the investment returns is observed. CARs are lower for mergers with the very short intervals between the new and previous acquisition. CARs also increase with the length of the time intervals. This implies that the frequency of the time interval is important to investors and their perception of the activity. With the longer interval at the same frequency, the stock market perceives a positive expectation of the new acquisition. This explains why given the same merger occurrence, some studies argue negatively against frequency and some argue positively for frequency. This is because evidence in support of their contradictory arguments fails to take into account the time interval between acquisitions. When the time interval effect is controlled, we report that CARs decrease with a higher frequency, which is consistent with the expectation of the hubris argument.

The finding above implies that not only is the high frequency of acquisition a negative value for a stock market regarding the integration of new business, but also that a low frequency can be negatively valued if the interval of frequency is short. The wavelength of merger frequency can change the investors' expectations and the investment returns. This new argument, supported by the global evidence associated with our study, makes the distinctive augmentation of existing research on M\&A and our understanding of how the frequency and frequent intervals of a merger can affect investors in the valuing of an announcement of new business integration.

The remainder of the paper is organized in the following way. The next section discusses the research method. Section 3 describes the data used in our empirical analysis. Section 4 presents findings from our analysis and their implications. Section 5 concludes the research.

\section{Research Method}

We took an event study approach to evaluate the effect of merger announcements on the stock value of the acquiring firm and compared the effects with different groups of merger frequency. There 
are three elements related to our research methodology. How to measure investment returns, how to define frequency and how to evaluate frequency, as discussed in turn below.

\section{$2.1 \quad$ Measures}

In terms of market reaction to the value of M\&A, Cumulative Abnormal Return is a commonly used methodology to measure financial performance. This is because it captures anticipated performance and avoids the problems of accounting-based measures, that are unable to differentiate between performance attributable to the combined firms and 'ordinary' performance that would have accrued to the acquirer and target if they had remained independent (Fich et al. 2018; Larsson and Finkelstein 1999).

We employ cumulative abnormal return as the measure of M\&A performance around the window of M\&A announcement based on the Brown and Warner (1985) market model. We do not estimate the individual risk (Beta) of each stock due to the insignificant relationship between Beta and stock returns (Brown and Warner 1985; Fama and French 1992). We estimate the following model in order to calculate abnormal returns (AR):

$$
A R_{i t}=R_{i t}-R_{m t}
$$

Where $R_{i t}$ is acquiring firm's daily stock returns on its stock $i$ at day $t ; R_{m t}$ is daily stock market returns (for the market on which the acquiring firm is listed) at day $t$.

We further compute accumulation of the daily abnormal returns to measure the CARs which is a measurement of the total abnormal returns during the event window:

$$
C A R_{i(T 1-T 2)}=\sum_{T 1}^{T 2} A R_{i t}
$$

Where $T 1$ is the starting date of the event window and $T 2$ is the end date of the event window. The average cumulative returns of $N$ firms for the period from $T 1$ to $T 2$ days can be expressed as follows:

$$
\overline{C A R}_{(T 1-T 2)}=\sum_{i=1}^{N} \frac{C A R_{i(T 1-T 2)}}{N}
$$


In our computation, we define the announcement day of an event as the starting date of an event (day 0). A longer window can capture more economic impact of the acquisition since the initial stock market reaction to the announcement of an acquisition is often incomplete or biased (Oler et al. 2008). A five-day event window $(-2,+2)$ around the announcement day (day 0 ) has been widely applied (Cox and Portes 1998; Faccio et al. 2006; Fuller et al. 2002; Gaur et al. 2013). Furthermore, if information is leaked before the announcement date of the official deal, it can capture the market reaction in day -1 (one day before the event day) or even -2 (two days before the event day). In line with these studies, we take a five-day event window $(-2,+2)$ for our computation of the CARs.

However, predictive power will decrease when more days are added into the event window (Mackinlay 1997) due to the likelihood of confounding effects from other events. A number of studies take a three-day event window $(-1,+1)$ and explain that one day after the event day, $($ day +1$)$ can reflect the market reaction when events occur after trading hours (Alexandridis et al. 2017; Ma et al. 2009). To reduce the probability of capturing confounding events in CAR calculations, we also consider the three-day event window, $(-1,+1)$ to compute CARs as a robustness check of our results of the five-day window (See Appendix).

\section{$2.2 \quad$ Frequency}

Regarding frequency, existing studies count the number of mergers emerged during a specific period as "frequency", and some split or classify the acquiring firms according to either a single acquirer that acquired only one target during the sample period, or a frequent acquirer that acquired more than one target in the sample period. Our frequency measure combines different approaches from existing studies. First, frequent acquirers are defined as those having completed at least five deals over a three-year window (Golubov et al. 2015). Second, we study the performance of firms involved in mergers by defining a firm that has at least five acquisitions as a frequent acquirer for a given time period. This follows the frequent acquirer definition of Fuller et al. (2002) and Gong et al. (2019). Third, Ismail (2008) broadly groups US acquisitions according to single and multiple (at least 
two acquisitions) acquirers. Fourth, Billett and Qian (2008) define a firm as a frequent acquirer if the company acquired at least two public targets during the sample period. Finally, Conn et al. (2005) further separate their sample and group UK acquisitions according to single acquirers, moderately (23 acquisitions) and highly (at least four acquisitions) acquisitive over the sample period.

Following these studies our paper defines the merger frequency as the number of acquisitions that occurred during the sample span. We group different frequencies according to infrequent, frequent and highly frequent acquirers over our sample time period from 2000 to 2018. An infrequent acquirer refers to a firm that has acquired only one target firm over this period. In contrast, a frequent acquirer refers to a firm that has pursued two to four M\&A during the period. A highly frequent acquirer has five M\&A or more over the same sample period. With this definition of frequency, the CARs of an acquiring firm or stock with $f$ frequency is calculated as follows:

$$
C A R_{i t}^{f}=\frac{\sum_{m=i}^{f} C A R_{i t m}}{f}
$$

Where, CAR is cumulative abnormal returns defined by equation $2, f$ is a merger frequency that counts the number of mergers made by $i^{\text {th }}$ acquiring firm during the time period $t . m$ indicates the $m^{\text {th }}$ merger of the $i^{\text {th }}$ firm during the same period at time $t$. CAR $R_{i t}^{f}$ is the $i^{\text {th }}$ acquirer's average returns earned from its $f$ number or frequency of the mergers and acquisitions over the period from the sample starting year to year $t$.

\subsection{Evaluation by Ranking}

In order to compare returns of investing in an infrequent acquirer, a frequent acquirer, and high frequent acquirer, we rank $C A R_{i t}^{f}$ according to $f$. If $C A R_{i t}^{f}$ is ranked higher with increasing $f$ as follows:

$\left.C A R_{\text {it }}^{f}\right|_{\text {infrequent merger }} ^{f=1}<\left.C A R_{\text {it }}^{f}\right|_{\text {frequent merger }} ^{2 \leq f \leq 4}<\left.C A R_{\text {it }}^{f}\right|_{\text {highly frequent merger }} ^{f \geq 5}$

[RANK ONE]

Or $C A R_{i t}^{F}$ is ranked higher with $F$ as $F^{t h}$ sequence of merger made by an acquiring firm $i$. 
$\left.C A R_{i t}^{F}\right|_{F=1}<\left.C A R_{i t}^{F}\right|_{F=2}<\ldots<\left.C A R_{i t}^{F}\right|_{F=n}$

[RANK ONE]

RANK ONE supports the expectation of the organisational learning hypothesis (OLH), which describes how firms can learn from the acquisition experience in the context of acquisition experience on acquirer performance (Castellaneta and Conti 2017; Muehlfeld et al. 2012). Since more experiences facilitate the management to be more capable for turning opportunities of a new business integration into a success. These expectations are also consistent with the acquirer's market timing considerations suggesting that frequent acquirers, buying consistently through economic-wide waves, are more likely to be successful (Rovit and Lemire 2003; Toxvaerd 2008). Alternatively, the technology synergy explanation is also supported as enriching technological resource portfolio (e.g. patent portfolio) results in unique synergies that can be adopted by the acquirer (Chondrakis 2016).

Otherwise, if $C A R_{i t}^{f}$ is ranked higher with decreasing $\mathrm{f}$, or $C A R_{i t}^{F}$ is ranked higher with decreasing $F$ as $F^{\text {th }}$ sequence of merger made by the acquiring firm $i$, which is as follows:

$\left.C A R_{\text {it }}^{f}\right|_{\text {infrequent merger }} ^{f=1}>\left.C A R_{\text {it }}^{f}\right|_{\text {frequent merger }} ^{2 \leq f \leq 4}>C A R_{\text {it }}^{f} \mid \begin{aligned} & f \geq 5 \\ & \text { highly frequent merger }\end{aligned}$ [RANK TWO]

or $\left.C A R_{i t}^{F}\right|_{F=1}>\left.C A R_{i t}^{F}\right|_{F=2}>\ldots>\left.C A R_{i t}^{F}\right|_{F=n}$ [RANK TWO]

RANK TWO supports the opposite arguments of the Managerial Hubris Hypothesis (Roll 1986) and Agency Theory (Jensen 1986). This is because when the management of the acquirer undertakes its first bid, they will be more careful in choosing a target and investing in the business of the target. Thus making a successful decision for the acquisition. However, once the management develops hubris from the initially successful merger experience, the management of the acquiring firm will be less careful about target selection and risk assessment of an acquisition (Anderson and Marshall 2007). This could result in paying excessive takeover premiums leading to value losses for subsequent deals.

Results of RANK ONE or RANK TWO may not be robust if the time interval between the new and previous acquisition is not taken into account. Stock investors may expect that at the same 
frequency, the longer interval can enhance the acquiring firm performance since it gains more time for management to digest opportunities and challenges brought by integration of new business. This assists the firm to be better prepared for the next new acquisition. Clearly, in addition to merger frequency, the time intervals as the wavelength of merger frequency is expected to affect the investors in valuing an announcement of a new acquisition. The mixed effect of merger frequency and its wavelength creates a difficulty in regarding frequency as a major cause to the RANK ONE or RANK TWO of CAR unless we can separate the two effects. Against this challenge, we can compose $C A R_{i, t}^{f}=C A R_{i, t+t 1-t 1}^{f}=C A R_{i, t 1+(t-t 1)}^{f}=C A R_{i, t 1+\Delta t}^{f}$, where the present date $\mathrm{t}$ of the new acquisition is defined as $t_{1}$, which is the previous date of acquisition plus a number of interval days accounted from $\mathrm{t}_{1}$ to $\mathrm{t}$. Through specifying $C A R_{i, t}^{f}=C A R_{i, t 1+\Delta t}^{f}$, we can refine RANK ONE or RANK TWO into RANK THREE or RANK FOUR respectively as:

$$
C A R_{i, t 1+\Delta t}^{f}<C A R_{i, t 1+\Delta t}^{f^{H}} \text { with } f<f^{H} \quad \text { [RANK THREE] }
$$

$$
\text { or } C A R_{i, t 1+\Delta t}^{f}>C A R_{i, t 1+\Delta t}^{f^{H}} \text { with } f<f^{H} \quad \text { [RANK FOUR] }
$$

Where ranking CAR by frequency $f$ is made for an identical time interval $\Delta$ t. The RANK THREE or FOUR of CAR is robust since the interval effect on investors is separated from frequency. Furthermore, we can extend RANK THREE or FOUR to rank CAR by time interval $\Delta t$ between the two mergers for a given frequency $f$ :

$$
C A R_{i, t 1+\Delta t}^{f}<C A R_{i, t 1+\Delta t^{H}}^{f} \quad \text { with } \Delta t<\Delta t^{H} \quad \text { [RANK FIVE] }
$$

Where RANK FIVE implies the effect of the wavelength of merger frequency on ranking CAR when the frequency is separated or controlled. RANK FIVE expects that investors will value the longer interval as 'good digesting' of previous acquisition for a new acquisition. The longer break between mergers will benefit acquirers when learning depends on the time of break between two events. Short 
periods do not allow acquiring firms to draw inferences and experience from past takeovers (Hayward 2002).

RANKS ONE to FIVE are our valuations of ranking CARs by frequency and time interval. These are applied to analyze CARs and explore how investors in valuing integration of new business relate to the frequency and wavelength.

\section{Data}

The worldwide data used for applying our ranking theory includes all acquisitions completed by global public companies from January 1, 2000 to December 31, 2018. The acquisition data is collected from the Thomson Financial Securities Data Corporation (SDC) Database. Stocks and other financial information related to acquiring firms are collected from DataStream. Following existing studies (e.g. Al Rahahleh and Wei 2012; Alexandridis et al. 2017; Boubakri et al. 2012; Fuller et al. 2002; Karolyi et al. 2012), the data is filtered further according to screens listed in Table 1. Thorough screening of DataStream data is required when it involves large numbers of individual equities in markets outside the U.S (Ince and Porter 2006). We consider days on which $90 \%$ or more of the stocks listed on a given exchange with zero return as non-trading days (Karolyi et al. 2012). A stock which has more than $80 \%$ zero return days in a given month is considered as an outlier. Moreover, for the best comparison with existing studies (Fuller et al. (2002), Moeller et al. (2004) and Alexandridis et al. (2010)), we employ a one-million US dollars cut-off point to avoid results being generated by very small deals. ${ }^{1}$

\section{[INSERT TABLE 1 HERE]}

After filtering all 204981 acquisitions through the conditions above, an edited sample for analysis is yielded, consisting of 24263 deals by 9500 acquirers across 81 countries. Table 2 reports summary

\footnotetext{
${ }^{1}$ We also use a larger cut-off of $\$ 50$ million and the results remain intact. The results (not reported) for the sake of brevity, are available from the authors upon request.
} 
statistics of the sample across countries. According to the classification by the World Bank, 29 out of the 81 countries in our sample are developed (Australia, Austria, Belgium, Bulgaria, Canada, Croatia, Cyprus, Denmark, Estonia, Finland, France, Germany, Greece, Iceland, Ireland, Italy, Japan, Luxembourg, Netherlands, New Zealand, Norway, Portugal, Slovenia, Singapore, Spain, Sweden, Switzerland, United Kingdom and United States) and 52 countries are developing (Anguilla, Argentina, Bahamas, Bahrain, Bermuda, Brazil, British Virgin, Cayman Islands, Chile, China, Colombia, Egypt, Faroe Islands, Gabon, Gibraltar, Guernsey, Hungary, India, Indonesia, Isle of Man, Israel, Jersey, Jordan, Kazakhstan, Kenya, Kuwait, Malaysia, Malta, Mexico, Monaco, Morocco, Myanmar(Burma), Netherlands Antilles, Nigeria, Pakistan, Peru, Poland, Qatar, Romania, Russia, Saudi Arabia, South Africa, South Korea, Thailand, Tunisia, Turkey, Ukraine, Uruguay, US Virgin Island, United Arab Emirate, Venezuela, and Zambia). In our final sample, there are 4638 deals (average value $\$ 695.8$ billion) completed by the infrequent acquirers, 9394 deals (average value $\$ 2393.9$ billion) made by the frequent acquirers, and 10231 deals (average value $\$ 5593.4$ billion) made by the highly frequent acquirers. Sample firms are regarded as an infrequent acquirer if they acquired one business during the sample period. A frequent acquirer is when firms purchased two to four companies over the period, and a high frequent acquirer is when firms obtained at least five or more acquisitions over the sample period. Moreover, Table 2 reports that the US firms make up a significant fraction of the sample. To account for this potential bias, we provide multivariate estimations by excluding US firms in the Appendix (Table A6). The results are quantitatively similar to the full sample estimations.

\section{[INSERT TABLE 2 HERE]}

In Table 3, all of the acquisitions are grouped according to frequency of acquisition. Infrequent consist of $19.1 \%$ in total, frequent are $38.7 \%$ in total and highly frequent are $42.2 \%$ of the total. The acquisitions made by each group of frequency are further divided into subgroups. First, by the methods of payment made by the acquiring firms, such as cash, stock exchange, and mixed payment methods in transactions (Fuller et al. 2002; Martin 1996). Second, by the ownership status of target 
firms through geography and industry, respectively. Panel A of Table 3 reports the number of acquisitions in terms of target ownership. Approximately, $46.4 \%$ of acquisitions are private targets, of those $20.5 \%$ are infrequent, compared with $37.6 \%$ that are frequent and $41.9 \%$ that are highly frequent. The private targets are the highest type of acquisitions in each of the three groups of frequency. The private targets are more attractive to the bidders than the public targets. This is due to the fact that acquirers can gain significant abnormal returns from taking over private firms by exploiting their private information of the market (Fuller et al. 2002; Moeller et al. 2004). Moreover, it is worth considering that deals involving listed targets tend to be larger and associated with a higher degree of reputational exposure given the heightened media attention that they typically receive (Dahya et al. 2016)

Panel B highlights payment methods used by acquiring firms when acquiring new business. $65.7 \%$ of acquisitions are paid by corporations using cash, of those $15.8 \%$ are infrequent, $37.4 \%$ are frequent, and $46.9 \%$ are highly frequent. Cash payment is mostly used for transactions because the acquisitions are of a smaller size while larger sized acquisitions are paid by the combination of stock and cash. Interestingly, in using equity as payment for transactions the frequent paid $40.9 \%$ of all deals. This is much higher than the other two groups, in which the infrequent completed $29.2 \%$ and the highly frequent had only $29.9 \%$.

Panel C reports that $70.5 \%$ of targets are domestic companies and only $29.5 \%$ of targets are foreign firms, suggesting that domestic targets are more favorable to acquirers than cross-border targets. This is possibly due to the information asymmetry between acquirers and foreign target firms. Panel D reveals that $68.1 \%$ of total deals are stretched out beyond acquirers' core business, and the rest of the $31.9 \%$ of deals originate in the bidders' own industry. However, the mean value of transactions for related acquisitions is much greater than for conglomerates, even after controlling for the number of mergers. This suggests that the acquiring firms are more confident in pursuing horizontal mergers due to the advantage of information and controlling capability. 


\section{[INSERT TABLE 3 HERE]}

\section{Univariate analysis}

On the basis of our edited sample data, we apply our ranking theory to examine two questions. First, is investors' perception of the value of an announcement of a new business integration related to the M\&A history of the acquirer? Second, how does the history of the acquirer's M\&A affect investors in valuing the new acquisition? In order to address these two questions, we need to discover if there is a consistent pattern of data to fit the theory of ranking.

\subsection{More mergers in the past decrease the value of the new acquisition}

Table 4 reports the univariate analysis of the five-day cumulative returns for acquisition announcements across different merger frequencies. Overall, it is clear that acquisitions announced by both the infrequent and frequent acquirers are valued by investors positively with respect to CARs as returns of investment over the announcement window of the event. Acquisitions announced by the high frequent acquirers are valued poorly by investors. The investment returns decrease with increasing merger frequency, fitting the theory of the RANK TWO. An acquirer with a history of more mergers is perceived negatively by investors for its new business integration. This pattern of the data appears consistently across five clusters of observations. For example, group acquisitions over a one-year span of observation - in which acquirers completed one, two to four or more acquisitions over a year (within one year); group acquisitions over a ten-year span of observation in which acquirers completed one, two to four or more acquisitions over 10 years (within ten years); and group acquisitions on a sample span of observation - in which acquirers completed one, two to four or more over 19 years. These clusters of the sample check whether the pattern of data is stable and consistent with different time spans of a sample or clusters. Also, this time-span-based sample can mitigate the possible effect of time interval. 
The robustness of the data pattern for the RANK TWO is further illustrated in Panel B of Table 4, which displays a decrease in investment returns with increasing frequency across different relative sizes of acquisitions. This is measured as the value of acquisition relative to the market value of the acquirer. The market value is calculated as of the month before the announcement date and is the product of the monthly price and common shares outstanding. Moreover, the robustness of the RANK TWO is also shown in Table 4, as the total sample is divided into the Asia, Europe, Americas, Africa and Oceania, developed and developing economies. The investors' negative perception of frequent mergers is consistent across different regions and economies. Alexandridis et al. (2010) state that different development stages or economies could affect investors' perception of the announcement of a merger event. This finding emerges continuously and consistently across subsamples of different ownerships of target firms and payment methods used in transactions (see Panel E and F of Table 4). Our comprehensive worldwide analysis shows more mergers in the past is negatively related to the return or the value of new acquisitions.

\section{[INSERT TABLE 4 HERE]}

\subsection{Merger sequencing and returns}

When the returns of mergers diminish with higher frequency, the returns should be coherently ranked from high to low with merger sequencing, which is another element stated by the RANK TWO. This point has been detected by Conn et al. (2005) and Billett and Qian (2008). They suggest that an initial successful acquisition as a first deal shall exhibit a higher positive abnormal return. To see the coherent relation of merger frequency to sequencing for investment returns, Panel A of Table 5 ranks CARs by merger sequencing order in terms of three groups of merger frequency: Infrequent, frequent and highly frequent. It shows that the first order of merger has the highest CARs. The lower return of subsequent mergers is robustly consistent across subsamples of different time periods, regions, target ownerships, payment methods and economic development stages, respectively (see Table A1). The 
consistent finding suggests that the hubris is expected to influence management more for subsequent acquisitions after the first business integration.

\section{[INSERT TABLE 5 HERE]}

\subsection{Interval of mergers}

The theory of RANK FIVE expects that investors will value a longer interval between a new merger and a previous one, because a longer interval could be perceived by investors as 'good digesting' of the previous acquisition for a new acquisition. The longer break between mergers will benefit acquirers when learning depends on the time of break between two events. Panel B of Table 5 shows evidence in support of the expectation of RANK FIVE. Concerning the previous and the new merger, it compares CARs of the one-year interval, the two-year interval and the longer-than-twoyear interval respectively. Clearly, for the overall sample, CARs of the one-year interval are lower than CARs of the two-year interval. The longer-than-two-year interval has the highest CARs.

The robust pattern of this ranking can be further illustrated by the result of comparing CARs of intervals using the subsample of the second merger from the first one, the third merger from the second one, and the fourth or higher-sequenced merger. Their comparative results are consistent. The shorter the interval the lower the CARs. Furthermore, our results in Table 5 also are consistent with findings in Table 4. Moreover, Figure 1 illustrates higher CARs with yearly increasing intervals between mergers over the time period 2000-2018. This implies that the interval of mergers in the past is relevant for investors in valuing new business integrations.

\section{[INSERT FIGURE 1 HERE]}

\section{Multivariate analysis}

The previous results analyze returns to acquirers using univariate comparisons. In this section, we perform multivariate tests on the impact of merger frequency and time interval on acquirer's returns, which controls for other confounding factors. For the announcement period, regressions are 
computed using standard ordinary least squares cross-sectional analysis. The dependent variable is the 5-day abnormal return. The frequent and highly frequent are dummies that are equal to one if the acquirer made two to four, and more acquisitions over the sample span, respectively. We also count the number of acquisitions (No. of deals) over the sample period as an alternative frequency measure. Time interval counts years between deals. The control variables include relative size calculated as the target deal value divided by acquirer market value as of one month before the announcement date. A set of dummy variables that determine if the target is acquired with cash, with a combination of stock and cash, the target is privately held or a subsidiary, if the target and the bidder are in the same industry and the geographical region. We also establish interaction variables between merger frequency/acquirer dummies (i.e. frequent and highly frequent) and time interval. We incorporate country dummies to mitigate any possible institutional bias. We account for industry effects by employing a dummy variable for four-digit level grouping of SIC codes. Finally, in each regression, year dummies are also estimated to capture possible time effects.

In Table 6, we present the results of regressing the acquirer's CARs. The low explanatory power of the regression is consistent with previous studies (e.g. Billett and Qian 2008; Fuller et al. 2002). In general, the findings are similar to the univariate analysis. The results in Table 6 reveal that frequent and highly frequent acquirer dummies and number of deals are significantly negative. This is consistent with our earlier findings that infrequent acquirers outperform frequent and highly frequent acquirers (See Models 1, 4, 5 and 6). Multivariate tests reveal that the returns are positively affected by time interval between deals, which supports the univariate analysis results (See Model 2, 3, 5 and 6$)^{2}$. Our results of Model 3 and Model 6 confirm the mix effect of the time interval and merger frequency. As we show in Models 1, 4, 5 and 6, investor reactions to the persistence of acquiring behavior are mainly negative. We discover that the coefficients of interaction variables are

\footnotetext{
${ }^{2}$ Here we cannot count time interval between deals for infrequent acquires because they only made one deal. Therefore, we use the frequent acquirers as the reference group.
} 
positive but not significant at conventional levels, suggesting that the longer break between mergers, allow acquiring firms to digest experiences and challenges from past takeovers.

With respect to the control variables, we do not find significant results for cross-border and industry related acquisitions. With regard to the method of payment, the coefficients on cash deal, are positive and significant, suggesting that the CARs associated with cash deals are less positive than those connected with stock deals. Relative size reveals a positive and significant impact on CARs and suggests that the market views larger deals more favorably. Overall, as can be seen, conclusions of the multivariate analysis are consistent with the univariate analysis ${ }^{3}$.

\section{[INSERT TABLE 6 HERE]}

\section{Conclusion}

Utilizing a dataset of 24,263 acquisitions collected from 81 countries over 19 years from 2000 to 2018 , we examine the impact of the acquirer's merger history in relation to frequency and interval of mergers on the value perception of investors in response to the announcement of new business integration. A univariate analysis is undertaken to explore the effects of merger frequency on cumulative abnormal returns for three groups of acquirers, respectively, the infrequent, the frequent and the highly frequent.

The comparative results of CARs show the pattern of RANK TWO where low frequent acquirers outperform highly frequent ones, which is significantly consistent and robust across different subsamples. The pattern is also robustly consistent when CARs are compared with different frequencies for a particular group of firms that acquire new business over the similar length of break time after the last acquisition, which clearly supports RANK FOUR. Furthermore, evidence supporting RANK FIVE has found that CARs are lower for mergers with a very short interval

\footnotetext{
${ }^{3}$ For robustness, all models are re-estimated on the basis of 3-day CARs. As shown in the Appendix (Table A5), our results are robust to different event day windows.
} 
between two mergers of a firm, and CARs increase with the interval of merger. The history of an acquirer in relation to its time break after its last acquisition matters for investors in valuing the new business integration of the acquirer.

For a given frequency of merger, the longer interval of a new merger after the last one will be valued positively by investors, or otherwise, negatively. This explains why, given the same merger frequency, some studies argue negatively against frequency, and some argue positively, because evidence in support of their contradictory arguments fails in taking into account the time interval between acquisitions. The multivariate regressions support the univariate results even after controlling for deal and acquirer characteristics. This paper contributes distinctively to the existing literature on studies of merger frequency and stock returns by extending our understanding on how the history of acquirers' mergers affect the value perception of investors, and stock returns in terms of not only merger numbers but also their time distribution.

While the overall results are encouraging, we cannot claim that the implication suggested in our research is complete. Further exploration based on additional variables or refinements could be tested in the long-run. If the long-run results mirror the short-run findings, then their conclusion based on short-run findings would be well supported. Complementary long-run analysis in this context is desired in order to reach a more accurate conclusion about shareholders' wealth effects (Rau and Vermaelen 1998). However, various performance measures are sensitive to the estimation methods for the long-run. In particular, if a positive or negative post-acquisition performance is a genuine phenomenon or a statistical artifact. For example, based on the equally weighted approach, this question was addressed by Agrawal et al. (1992) and Franks et al. (1991). The former measured abnormal returns by adding up the average monthly returns estimated by Dimson and Marsh (1986)'s method and found that stockholders of the acquiring firms suffer a statistically significant wealth loss. While the latter's conclusion runs completely contrary when using the intercept of a regression using monthly returns on various factors. Conclusions based on Buy-and-Hold Abnormal Returns (BHAR) also lack reliability. For instance, Mitchell and Stafford (2000) reexamined the reliability and found 
a similar negative performance effect as documented in Loughran and Vijh (1997), but no evidence to support Rau and Vermaelen (1998)'s result of outperformance of acquirers with low book-tomarket ratio against acquirers with high book-to-market ratio. They report that the BHAR approach is severely flawed due to the ignorance of the cross-sectional dependence of abnormal returns.

The short-run event studies are relatively stable and free of limitations, even though they do not reflect the full impact of acquisitions. On the other hand, the interpretation and reliability of longrun results is quite problematic. In this respect, the resolution of this anomaly remains an avenue for future research. In addition, limited to unstandardized treatment of global R\&D and patent data, future studies could introduce performance indicators based on impact of innovation or technology synergy. 


\section{References}

Agrawal A, Jaffe JF, Mandelker GN (1992) The post- merger performance of acquiring firms: A re- examination of an anomaly The Journal of Finance 47:1605-1621

Aktas N, Croci E, Simsir SA (2016) Corporate governance and takeover outcomes 24:242-252

Aktas N, De Bodt E, Roll R (2011) Serial acquirer bidding: An empirical test of the learning hypothesis Journal of Corporate Finance 17:18-32

Al-Laham A, Schweizer L, Amburgey TL (2010) Dating before marriage? Analyzing the influence of pre-acquisition experience and target familiarity on acquisition success in the " $\mathrm{m} \& \mathrm{a}$ as r\&d" type of acquisition Scandinavian Journal of Management 26:25-37

Al Rahahleh N, Wei PP (2012) The performance of frequent acquirers: Evidence from emerging markets Global Finance J 23:16-33

Alexandridis G, Antypas N, Travlos N (2017) Value creation from m\&as: New evidence Journal of Corporate Finance 45:632-650

Alexandridis G, Petmezas D, Travlos NG (2010) Gains from mergers and acquisitions around the world: New evidence Finan Manage 39:1671-1695

Amor SB, Kooli M (2016) Do acquisitions affect ipo long-run performance? Evidence from single vs. Multiple acquirers J Int Finan Markets, Inst Money 40:63-79

Anderson HD, Marshall BR (2007) Takeover motives in a weak regulatory environment surrounding a market shock: A case study of new zealand with a comparison of gondhalekar and bhagwat's (2003) us findings Rev Quant Finance Acc 29:53-67

Ang SH, Benischke MH, Hooi AW-L (2018) Frequency of international expansion through high control market expansion modes and interlocked directorships J World Bus 53:493-503

Antoniou A, Zhao H (2007) What drives acquisitions? A market-manager rationality framework. In: Mergers and Acquisitions. Springer, pp 5-26

Arikan AM, Stulz RM (2016) Corporate acquisitions, diversification, and the firm's life cycle The Journal of Finance 71:139-194

Ashkenas RN, Demonaco LJ, Francis SC (1997) Making the deal real: How ge capital integrates acquisitions. Harvard Business Review,

Avkiran NK (1999) The evidence on efficiency gains: The role of mergers and the benefits to the public J Banking Finance 23:991-1013

Barkema HG, Bell JH, Pennings JM (1996) Foreign entry, cultural barriers, and learning Strategic Management Journal 17:151-166

Basuil Da, Datta DK (2015) Effects of industry- and region- specific acquisition experience on value creation in cross- border acquisitions: The moderating role of cultural similarity Journal of Management Studies 52:766-795

Bena J, Li K (2014) Corporate innovations and mergers and acquisitions The Journal of Finance 69:1923-1960

Billett MT, Qian Y (2008) Are overconfident ceos born or made? Evidence of self-attribution bias from frequent acquirers Management Science 54:1037-1051

Boubakri N, Cosset JC, Saffar W (2012) The impact of political connections on firms'operating performance and financing decisions J Finan Res 35:397-423 
Brown SJ, Warner JB (1985) Using daily stock returns: The case of event studies J Finan Econ $14: 3-31$

Bruton GD, Oviatt BM, White MA (1994) Performance of acquisitions of distressed firms Academy of Management Journal 37:972-989

Canace TG, Mann SV (2014) The impact of technology-motivated m\&a and joint ventures on the value of it and non-it firms: A new examination Rev Quant Finance Acc 43:333-366

Cassiman B, Veugelers R (2006) In search of complementarity in innovation strategy: Internal R\&D and external knowledge acquisition Management science 52:68-82

Castellaneta F, Conti R (2017) How does acquisition experience create value? Evidence from a regulatory change affecting the information environment European Management Journal $35: 60-68$

Chang M, Yu J, Adamson W (2018) How directors trade and learn during takeovers Pacific-Basin Finance J 51:184-197

Chao Y-C (2018) Organizational learning and acquirer performance: How do serial acquirers learn from acquisition experience? Asia Pacific Management Review 23:161-168

Chondrakis G (2016) Unique synergies in technology acquisitions Res Pol 45:1873-1889

Chuang K-S (2018) Glamour versus value, market timing and firm performance: Evidence from mergers and acquisitions Rev Quant Finance Acc 51:967-1003

Conn RL, Cosh A, Guest PM, Hughes A (2005) The impact on uk acquirers of domestic, crossborder, public and private acquisitions Journal of Business Finance \& Accounting 32:815870

Cox AJ, Portes J (1998) Mergers in regulated industries: The uses and abuses of event studies J Regul Econ 14:281-304

Croci E, Petmezas D (2009) Why do managers make serial acquisitions? An investigation of performance predictability in serial acquisitions An Investigation of Performance Predictability in Serial Acquisitions (April 2009)

Dahya J, Golubov A, Petmezas D, Travlos NG (2016) Governance mandates, outside directors, and acquirer performance Journal of Corporate Finance

Degbey WY (2015) Customer retention: A source of value for serial acquirers Industrial Marketing Management 46:11-23

Dimson E, Marsh P (1986) Event study methodologies and the size effect: The case of uk press recommendations J Finan Econ 17:113-142

Dong M, Hirshleifer D, Richardson S, Teoh SH (2006) Does investor misvaluation drive the takeover market? The Journal of Finance 61:725-762

Faccio M, Mcconnell JJ, Stolin D (2006) Returns to acquirers of listed and unlisted targets J Finan Quant Anal 41:197-220

Faff R, Prasadh S, Shams S (2019) Merger and acquisition research in the asia-pacific region: A review of the evidence and future directions Research in International Business and Finance $50: 267-278$

Fama EF, French KR (1992) The cross- section of expected stock returns The Journal of Finance 47:427-465 
Fich EM, Nguyen T, Officer M (2018) Large wealth creation in mergers and acquisitions Finan Manage 47:953-991

Field LC, Mkrtchyan A (2017) The effect of director experience on acquisition performance J Finan Econ 123:488-511

Fowler KL, Schmidt DR (1989) Determinants of tender offer post-acquisition financial performance Strategic Management Journal 10:339-350

Franks J, Harris R, Titman S (1991) The postmerger share-price performance of acquiring firms J Finan Econ 29:81-96

Fuller K, Netter J, Stegemoller M (2002) What do returns to acquiring firms tell us? Evidence from firms that make many acquisitions The Journal of Finance 57:1763-1793

Gaur AS, Malhotra S, Zhu P (2013) Acquisition announcements and stock market valuations of acquiring firms' rivals: A test of the growth probability hypothesis in china Strategic Management Journal 34:215-232

Golubov A, Yawson A, Zhang H (2015) Extraordinary acquirers J Finan Econ 116:314-330

Gong Y, Zhang Y, Xia J (2019) Do firms learn more from small or big successes and failures? A test of the outcome-based feedback learning perspective 45:1034-1056

Harford J, Schonlau RJ (2013) Does the director labor market offer ex post settling-up for ceos? The case of acquisitions J Finan Econ 110:18-36

Hayward ML (2002) When do firms learn from their acquisition experience? Evidence from 1990 to 1995 Strategic Management Journal 23:21-39

Heeley MB, King DR, Covin JG (2006) Effects of firm r\&d investment and environment on acquisition likelihood Journal of Management Studies 43:1513-1535

Hitt M, Harrison J, Ireland RD, Best A (1998) Attributes of successful and unsuccessful acquisitions of us firms British Journal of Management 9:91-114

Humphery-Jenner M (2014) Takeover defenses, innovation, and value creation: Evidence from acquisition decisions Strategic Management Journal 35:668-690

Ince OS, Porter RB (2006) Individual equity return data from thomson datastream: Handle with care! J Finan Res 29:463-479

Ismail A (2008) Which acquirers gain more, single or multiple? Recent evidence from the USA market Global Finance J 19:72-84

Ismail A, Abdallah AA (2013) Acquirer's return and the choice of acquisition targets: Does acquisition experience matter? Appl Econ 45:3770-3777

Jensen MC (1986) Agency cost of free cash flow, corporate finance, and takeovers Amer Econ Rev 76

Kamien MI, Zang I (1993) Monopolization by sequential acquisition Journal of Law, Economics, \& Organization 9:205-229

Karolyi GA, Lee K-H, Van Dijk MA (2012) Understanding commonality in liquidity around the world J Finan Econ 105:82-112

Klasa S, Stegemoller M (2007) Takeover activity as a response to time- varying changes in investment opportunity sets: Evidence from takeover sequences Finan Manage 36:1-25 
Kusewitt JB (1985) An exploratory study of strategic acquisition factors relating to performance Strategic Management Journal 6:151-169

Laamanen T, Keil T (2008) Performance of serial acquirers: Toward an acquisition program perspective Strategic Management Journal 29:663-672

Larsson R, Finkelstein S (1999) Integrating strategic, organizational, and human resource perspectives on mergers and acquisitions: A case survey of synergy realization Organization Science 10:1-26

Lin J-C, Wang Y (2016) The R\&D premium and takeover risk The Accounting Review 91:955-971

Loughran T, Vijh AM (1997) Do long- term shareholders benefit from corporate acquisitions? The Journal of Finance 52:1765-1790

Ma J, Pagan Ja, Chu Y (2009) Abnormal returns to mergers and acquisitions in ten asian stock markets Int J Bus 14:235

Mackinlay aC (1997) Event studies in economics and finance J Econ Lit 35:13-39

Malmendier U, Tate G (2008) Who makes acquisitions? Ceo overconfidence and the market's reaction J Finan Econ 89:20-43

Martin KJ (1996) The method of payment in corporate acquisitions, investment opportunities, and management ownership The Journal of Finance 51:1227-1246

Mitchell ML, Stafford E (2000) Managerial decisions and long- term stock price performance The Journal of Business 73:287-329

Moeller SB, Schlingemann FP, Stulz RM (2004) Firm size and the gains from acquisitions J Finan Econ 73:201-228

Muehlfeld K, Rao Sahib P, Van Witteloostuijn A (2012) A contextual theory of organizational learning from failures and successes: A study of acquisition completion in the global newspaper industry, 1981-2008 Strategic Management Journal 33:938-964

Nadolska A, Barkema HG (2014) Good learners: How top management teams affect the success and frequency of acquisitions Strategic Management Journal 35:1483-1507

Nam C, Yang D-H, Park M-C, Oh G-H, Park J-H (2005) Stock market reaction to mergers and acquisitions in anticipation of a subsequent related significant event: Evidence from the korean telecommunications industry Review of Pacific Basin Financial Markets and Policies $08: 185-200$

Oler DK, Harrison JS, Allen MR (2008) The danger of misinterpreting short-window event study findings in strategic management research: An empirical illustration using horizontal acquisitions Strategic Organization 6:151-184

Perkins DN, Salomon G (1992) Transfer of learning International Encyclopedia of Education 2:6452-6457

Rau PR, Vermaelen T (1998) Glamour, value and the post-acquisition performance of acquiring firms J Finan Econ 49:223-253

Rhodes- Kropf M, Viswanathan S (2004) Market valuation and merger waves The Journal of Finance 59:2685-2718

Roll R (1986) The hubris hypothesis of corporate takeovers The Journal of Business:197-216

Rovit S, Lemire C (2003) Your Best M\&A Strategy Harvard Bus Rev 81:16-17 
Savor PG, Lu QJtJoF (2009) Do stock mergers create value for acquirers? 64:1061-1097

Schipper K, Thompson R (1983) Evidence on the capitalized value of merger activity for acquiring firms J Finan Econ 11:85-119

Shih Y-C, Hsu B-J (2009) Does stock misvaluation differentiate the motives for takeovers? Review of Pacific Basin Financial Markets and Policies 12:545-566

Shleifer A, Vishny RW (2003) Stock market driven acquisitions J Finan Econ 70:295-311

Toxvaerd F (2008) Strategic merger waves: A theory of musical chairs J Econ Theory 140:1-26

Trichterborn A, Knyphausen- Aufseß Z, Schweizer L (2015) How to improve acquisition performance: The role of a dedicated $m \& a$ function, $m \& a$ learning process, and $m \& a$ capability Strategic Management Journal

Vermaelen T, Xu M (2014) Acquisition finance and market timing J Corp Finan: Contracting, Governance Organ 25:73-91 


\section{Appendix}

Table A.1. Univariate analysis of 5-day cumulative abnormal returns by dear order

\begin{tabular}{|c|c|c|c|c|c|c|}
\hline \multirow{2}{*}{ Deal order } & \multicolumn{2}{|c|}{$1^{\text {st }}$} & \multicolumn{2}{|c|}{$2^{\mathrm{nd}}-3^{\mathrm{rd}}$} & \multicolumn{2}{|l|}{$>=4^{\text {th }}$} \\
\hline & CAR $[+2,-2]$ & $N$ & CAR $[+2,-2]$ & $N$ & $\mathrm{CAR}[+2,-2]$ & $N$ \\
\hline \multicolumn{7}{|l|}{ Panel A: Time period } \\
\hline $2000-2009$ & $\begin{array}{c}3.26 \%{ }^{* * * *} \\
(19.00)\end{array}$ & 4188 & $\begin{array}{c}1.88 \%{ }^{* \% \%} \\
(13.05)\end{array}$ & 2837 & $\begin{array}{c}0.93 \%{ }^{* * * *} \\
(8.07)\end{array}$ & 2214 \\
\hline 2010-2018 & $\begin{array}{c}4.13 \% \\
(24.82)\end{array}$ & 5312 & $\begin{array}{c}3.00 \% \\
(21.83)\end{array}$ & 4880 & $\begin{array}{c}1.52 \%{ }^{* * *} \\
(17.16)\end{array}$ & 4832 \\
\hline \multicolumn{7}{|l|}{ Panel B: Regions } \\
\hline Asia & $\begin{array}{c}2.96 \% \\
(20.57)\end{array}$ & 4177 & $\begin{array}{c}2.30 \% \\
(14.47)\end{array}$ & 2886 & $\begin{array}{c}1.00 \% \\
(6.26)\end{array}$ & 1495 \\
\hline Europe & $\begin{array}{c}2.97 \%{ }^{* * *} \\
(12.37)\end{array}$ & 1580 & $\begin{array}{c}2.31 \%{ }^{* * *} \\
(12.50)\end{array}$ & 1549 & $\begin{array}{c}1.60 \%{ }^{* * *} \\
(13.52)\end{array}$ & 2052 \\
\hline Americas & $\begin{array}{c}4.29 \%{ }^{* * * *} \\
(16.99)\end{array}$ & 2925 & $\begin{array}{c}2.61 \%{ }^{* * *} \\
(14.36)\end{array}$ & 2704 & $\begin{array}{c}1.23 \%{ }^{* * *} \\
(11.50)\end{array}$ & 3210 \\
\hline Africa & $\begin{array}{c}1.65 \%{ }^{* *} \\
(2.60)\end{array}$ & 91 & $\begin{array}{c}1.70 \%{ }^{* *} \\
(2.01)\end{array}$ & 59 & $\begin{array}{l}0.03 \% \\
(0.03)\end{array}$ & 29 \\
\hline Oceania & $\begin{array}{c}8.09 \% \\
(12.20)\end{array}$ & 721 & $\begin{array}{c}5.08 \% \\
(9.29) \\
\end{array}$ & 515 & $\begin{array}{c}2.73 \%{ }^{* * * *} \\
(5.74)\end{array}$ & 252 \\
\hline \multicolumn{7}{|c|}{ Panel C: Economic development } \\
\hline Developing economies & $\begin{array}{c}3.66 \% \\
(18.44)\end{array}$ & 2346 & $\begin{array}{c}2.47 \% \\
(10.32)\end{array}$ & 2174 & $\begin{array}{c}1.48 \% \\
(5.50)\end{array}$ & 1188 \\
\hline Developed economies & $\begin{array}{c}3.85 \%{ }^{* * * *} \\
(26.57) \\
\end{array}$ & 7154 & $\begin{array}{c}1.95 \% \%^{* * *} \\
(15.10) \\
\end{array}$ & 5758 & $\begin{array}{c}1.34 \%{ }^{* * *} \\
(18.37) \\
\end{array}$ & 5643 \\
\hline \multicolumn{7}{|c|}{ Panel D: Target ownership } \\
\hline Public & $\begin{array}{c}1.69 \% \\
(7.58)\end{array}$ & 1434 & $\begin{array}{c}1.27 \%{ }^{* * *} \\
(5.96)\end{array}$ & 1347 & $\begin{array}{c}0.53 \%{ }^{* * *} \\
(3.59)\end{array}$ & 1359 \\
\hline Private & $\begin{array}{c}4.60 \%{ }^{* * *} \\
(23.36)\end{array}$ & 4520 & $\begin{array}{c}3.02 \%{ }^{* * *} \\
(18.78)\end{array}$ & 3480 & $\begin{array}{c}1.47 \%{ }^{* * *} \\
(14.21)\end{array}$ & 3257 \\
\hline Subsidiary & $\begin{array}{c}3.50 \%{ }^{* * *} \\
(19.68)\end{array}$ & 3546 & $\begin{array}{c}2.68 \%{ }^{* * *} \\
(16.51) \\
\end{array}$ & 2890 & $\begin{array}{c}1.60 \%{ }^{* * *} \\
(12.72)\end{array}$ & 2430 \\
\hline \multicolumn{7}{|l|}{ Panel E: Payment method } \\
\hline Pure cash & $\begin{array}{l}2.37 \% \\
(20.72)\end{array}$ & 5420 & $\begin{array}{l}2.02 \% \\
(19.04)\end{array}$ & 5064 & $\begin{array}{l}1.23 \% \\
(17.35)\end{array}$ & 5454 \\
\hline Pure stock & $\begin{array}{c}5.31 \%{ }^{* * *} \\
(16.55)\end{array}$ & 2255 & $\begin{array}{c}3.24 \% \\
(10.14)\end{array}$ & 1262 & $\begin{array}{c}2.89 \%^{* * *} \\
(3.34)\end{array}$ & 697 \\
\hline Combination & $\begin{array}{c}5.91 \%{ }^{* * *} \\
(17.78) \\
\end{array}$ & 1825 & $\begin{array}{c}4.06 \%{ }^{* * * *} \\
(14.03)\end{array}$ & 1391 & $\begin{array}{c}2.30 \%{ }^{* * *} \\
(8.20)\end{array}$ & 895 \\
\hline
\end{tabular}

This table presents the analysis of 5-day CARs across deal order. In Panel A, acquisitions are grouped by time periods over 2000 2009, and 2010 - 2018. For Panel C, countries are organized using World Bank classifications. In Panel E, cash offers include cash only and mixtures of cash and debt, stock offers include common stock only or a combination of common stock and options, warrants, or rights, and mixed deals are comprised of some proportion of cash and stock. $t$-statistics are reported in parentheses. ${ }^{*}, * *, * * *$ represent significance at the $1 \%, 5 \%$ and $10 \%$ level, respectively. 
Table A.2. Univariate analysis of 3-day cumulative abnormal returns by M\&A frequency

\begin{tabular}{|c|c|c|c|c|c|c|}
\hline & \multicolumn{2}{|c|}{ Infrequent } & \multicolumn{2}{|c|}{ Frequent } & \multicolumn{2}{|c|}{ Highly frequent } \\
\hline & CAR $[-1,+1]$ & $N$ & CAR $[-1,+1]$ & $N$ & CAR $[-1,+1]$ & $N$ \\
\hline \multicolumn{7}{|c|}{ Panel A: Time span of observation } \\
\hline Within one year & $\begin{array}{c}2.32 \% \\
(31.79)\end{array}$ & 16343 & $\begin{array}{l}1.50 \% \\
(18.31)\end{array}$ & 7231 & $\begin{array}{c}1.34 \% \\
(6.97)\end{array}$ & 689 \\
\hline Within five years & $\begin{array}{c}3.50 \%{ }^{* * * *} \\
(25.07)\end{array}$ & 5972 & $\begin{array}{c}2.39 \%{ }^{* * * *} \\
(33.00)\end{array}$ & 11525 & $\begin{array}{c}1.49 \%{ }^{* * * *} \\
(22.59)\end{array}$ & 6766 \\
\hline Within ten years & $\begin{array}{c}3.62 \%{ }^{* * *} \\
(23.54)\end{array}$ & 5022 & $\begin{array}{c}2.62 \%{ }^{* * *} \\
(31.95)\end{array}$ & 10333 & $\begin{array}{c}1.59 \%{ }^{* * *} \\
(25.35)\end{array}$ & 8908 \\
\hline Within fifteen years & $\begin{array}{c}3.69 \%{ }^{* * * *} \\
(22.82)\end{array}$ & 4686 & $\begin{array}{c}2.65 \%{ }^{* * * *} \\
(30.82)\end{array}$ & 9691 & $\begin{array}{l}1.67 \%{ }^{* * * *} \\
(27.50)\end{array}$ & 9886 \\
\hline Within sample span & $\begin{array}{c}3.71 \%{ }^{* * *} \\
(22.72)\end{array}$ & 4638 & $\begin{array}{c}2.68 \%{ }^{* * *} \\
(30.40)\end{array}$ & 9394 & $\begin{array}{c}1.78 \%{ }^{* * *} \\
(28.10)\end{array}$ & 10231 \\
\hline \multicolumn{7}{|l|}{ Panel B:Relative size } \\
\hline$<5 \%$ & $\begin{array}{c}1.02 \%{ }^{* * *} \\
(6.33)\end{array}$ & 1401 & $\begin{array}{c}0.94 \%{ }^{* * *} \\
(10.12)\end{array}$ & 3951 & $\begin{array}{c}0.69 \%{ }^{* * * *} \\
(11.93)\end{array}$ & 6197 \\
\hline$\left[\begin{array}{llllllll}5 \% & 15 \%\end{array}\right.$ & $\begin{array}{c}2.36 \%{ }^{* * *} \\
(10.29)\end{array}$ & 1076 & $\begin{array}{c}2.30 \%^{* * * *} \\
(12.27)\end{array}$ & 2320 & $\begin{array}{c}2.08 \%{ }^{* * *} \\
(17.17)\end{array}$ & 2189 \\
\hline$[15 \% 25 \%]$ & $\begin{array}{c}4.04 \%{ }^{* * *} \\
(8.01)\end{array}$ & 500 & $\begin{array}{c}3.04 \%{ }^{* * *} \\
(9.56)\end{array}$ & 949 & $\begin{array}{c}2.80 \%{ }^{* * *} \\
(10.82)\end{array}$ & 679 \\
\hline$>25 \%$ & $\begin{array}{c}6.36 \%{ }^{* * *} \\
(16.96)\end{array}$ & 1661 & $\begin{array}{c}3.62 \%{ }^{* * *} \\
(11.71)\end{array}$ & 2174 & $\begin{array}{c}3.68 \%{ }^{* * *} \\
(12.57)\end{array}$ & 1166 \\
\hline \multicolumn{7}{|l|}{ Panel C: Region } \\
\hline Asia & $\begin{array}{c}3.24 \%{ }^{* * *} \\
(8.80)\end{array}$ & 2269 & $\begin{array}{c}2.22 \%{ }^{* * *} \\
(12.60)\end{array}$ & 4116 & $\begin{array}{l}1.63 \%{ }^{* * *} \\
(17.14)\end{array}$ & 2173 \\
\hline Europe & $\begin{array}{c}2.21 \%{ }^{* * *} \\
(14.89)\end{array}$ & 647 & $\begin{array}{c}1.98 \%{ }^{* * *} \\
(15.88)\end{array}$ & 1593 & $\begin{array}{c}1.41 \%{ }^{* * *} \\
(11.74)\end{array}$ & 2941 \\
\hline Americas & $\begin{array}{c}4.95 \%{ }^{* * *} \\
(12.62)\end{array}$ & 1281 & $\begin{array}{c}2.08 \%{ }^{* * * *} \\
(9.44)\end{array}$ & 2853 & $\begin{array}{c}1.49 \%{ }^{* * *} \\
(16.62)\end{array}$ & 4705 \\
\hline Africa & $\begin{array}{c}1.77 \%{ }^{* *} \\
(2.53)\end{array}$ & 49 & $\begin{array}{l}0.29 \% \\
(0.53)\end{array}$ & 87 & $\begin{array}{l}-0.04 \% \\
(-0.06)\end{array}$ & 43 \\
\hline Oceania & $\begin{array}{c}8.67 \% \%^{* * *} \\
(9.06) \\
\end{array}$ & 388 & $\begin{array}{c}3.28 \%{ }^{* * *} \\
(6.71) \\
\end{array}$ & 742 & $\begin{array}{c}2.64 \%{ }^{* * *} \\
(8.34) \\
\end{array}$ & 358 \\
\hline \multicolumn{7}{|c|}{ Panel D:Economic development } \\
\hline Developing economies & $\begin{array}{c}4.09 \% \\
(19.37)\end{array}$ & 1294 & $\begin{array}{l}2.00 \% \\
(16.33)\end{array}$ & 2952 & $\begin{array}{l}1.52 \% \\
(25.85)\end{array}$ & 1462 \\
\hline Developed economies & $\begin{array}{c}2.64 \%{ }^{* * *} \\
(12.72) \\
\end{array}$ & 3344 & $\begin{array}{c}2.32 \%{ }^{* * *} \\
(14.24) \\
\end{array}$ & 7042 & $\begin{array}{c}1.99 \%{ }^{* * *} \\
(9.50) \\
\end{array}$ & 8169 \\
\hline \multicolumn{7}{|c|}{ Panel E:Target ownership } \\
\hline Public & $\begin{array}{c}1.66 \%{ }^{* * *} \\
(5.02)^{* * * *}\end{array}$ & 565 & $\begin{array}{c}1.15 \%{ }^{* * *} \\
(6.12)^{*}\end{array}$ & 1460 & $\begin{array}{c}0.71 \%{ }^{* * *} \\
(6.42)^{* * * *}\end{array}$ & 2115 \\
\hline Private & $\begin{array}{c}4.40 \%{ }^{* * *} \\
(16.52)\end{array}$ & 2,305 & $\begin{array}{l}3.14 \%^{* * *} \\
(21.56)\end{array}$ & 4235 & $\begin{array}{l}1.78 \%{ }^{* * *} \\
(20.50)\end{array}$ & 4717 \\
\hline Subsidiary & $\begin{array}{c}3.30 \%{ }^{* * *} \\
(14.43) \\
\end{array}$ & 1768 & $\begin{array}{c}2.60 \%^{* * *} \\
(19.94) \\
\end{array}$ & 3699 & $\begin{array}{c}1.74 \%{ }^{* * *} \\
(17.52) \\
\end{array}$ & 3399 \\
\hline \multicolumn{7}{|c|}{ Panel F: Payment method } \\
\hline Pure cash & $\begin{array}{c}2.31 \% \\
(14.78)\end{array}$ & 2511 & $\begin{array}{l}1.83 \% \\
(21.05)\end{array}$ & 5955 & $\begin{array}{l}1.27 \%{ }^{* * *} \\
(22.92)\end{array}$ & 7472 \\
\hline Pure stock & $\begin{array}{l}5.35 \%^{* * *} \\
(12.86)\end{array}$ & 1229 & $\begin{array}{l}3.85 \%^{* * *} \\
(13.90)^{* * *}\end{array}$ & 1723 & $\begin{array}{c}1.65 \%^{* * *} \\
(8.38)^{* * *}\end{array}$ & 1262 \\
\hline Hybrid & $\begin{array}{c}5.04 \%{ }^{* * *} \\
(11.57)\end{array}$ & 898 & $\begin{array}{c}4.14 \%{ }^{* * *} \\
(16.35)\end{array}$ & 1716 & $\begin{array}{c}2.84 \%^{* * * *} \\
(13.28)\end{array}$ & 1497 \\
\hline
\end{tabular}

This table presents the analysis of 3-day CARs based on different sub-samples. In Panel A, acquisitions are grouped by one, five, ten, fifteen-year span of observation - in which acquirers completed one, two to four or more acquisitions over one, five, ten, fifteen year(s), and a 19-year span of observation - in which acquirers completed one, two to four or more over the sample span. Percentages in 'All' column are computed by dividing the deal counts for an individual row by the total number of deals. For the rest of the rows, a percent shows the proportion of deals in a column category from among those in the row. For Panel D, countries are organized using World Bank classifications. In Panel F, cash offers include cash only and mixtures of cash and debt, stock offers include common stock only or a combination of common stock and options, warrants, or rights, and mixed deals are comprised of some proportion of cash and stock. Relative size is computed as the natural log of target deal value divided by acquirer market value as of one month before the announcement date. $t$-statistics are reported in parentheses. ${ }^{*}, * *, * * *$ represent significance at the $1 \%, 5 \%$ and $10 \%$ level, respectively. 
Table A.3. Univariate analysis of 3-day cumulative abnormal returns by deal order

\begin{tabular}{|c|c|c|c|c|c|c|}
\hline \multirow{2}{*}{ Deal order } & \multicolumn{2}{|l|}{$1^{\text {st }}$} & \multicolumn{2}{|c|}{$2^{\text {nd }}-3^{\text {rd }}$} & \multicolumn{2}{|l|}{$>=4^{\text {th }}$} \\
\hline & CAR $[-1,+1]$ & $N$ & CAR $[-1,+1]$ & $N$ & CAR $[-1,+1]$ & $N$ \\
\hline \multicolumn{7}{|l|}{ Panel A: Time period } \\
\hline $2000-2009$ & $\begin{array}{c}2.76 \% \\
(18.82)\end{array}$ & 4188 & $\begin{array}{c}1.67 \% \\
(13.46)\end{array}$ & 2837 & $\begin{array}{c}0.79 \% \\
(8.37)\end{array}$ & 2214 \\
\hline 2010-2018 & $\begin{array}{c}3.68 \%{ }^{* * *} \\
(25.65)\end{array}$ & 5312 & $\begin{array}{c}2.65 \%{ }^{* * *} \\
(22.39)\end{array}$ & 4880 & $\begin{array}{c}1.40 \%{ }^{* * *} \\
(17.95)\end{array}$ & 4832 \\
\hline \multicolumn{7}{|l|}{ Panel B: Regions } \\
\hline Asia & $\begin{array}{l}2.51 \% \\
(21.63)\end{array}$ & 4177 & $\begin{array}{c}2.05 \% \\
(16.24)\end{array}$ & 2886 & $\begin{array}{c}0.80 \% \\
(6.24)\end{array}$ & 1495 \\
\hline Europe & $\begin{array}{c}2.68 \%{ }^{* * *} \\
(12.97)\end{array}$ & 1580 & $\begin{array}{c}2.05 \%{ }^{* * * *} \\
(12.68)\end{array}$ & 1549 & $\begin{array}{c}1.48 \%{ }^{* * *} \\
(14.26)\end{array}$ & 2052 \\
\hline Americas & $\begin{array}{c}3.84 \%{ }^{* * * *} \\
(17.22)\end{array}$ & 2925 & $\begin{array}{c}2.44 \%{ }^{* * * *} \\
(14.37)\end{array}$ & 2704 & $\begin{array}{c}1.15 \%{ }^{* * * *} \\
(12.16)\end{array}$ & 3210 \\
\hline Africa & $\begin{array}{c}1.02 \%{ }^{* *} \\
(2.12)\end{array}$ & 91 & $\begin{array}{l}0.83 \% \\
(1.47)\end{array}$ & 59 & $\begin{array}{l}0.40 \% \\
(0.54)\end{array}$ & 29 \\
\hline Oceania & $\begin{array}{c}7.06 \%{ }^{* * *} \\
(12.03) \\
\end{array}$ & 721 & $\begin{array}{c}3.76 \%{ }^{* * *} \\
(8.56) \\
\end{array}$ & 515 & $\begin{array}{c}2.37 \%{ }^{* * *} \\
(5.57) \\
\end{array}$ & 252 \\
\hline \multicolumn{7}{|c|}{ Panel C: Economic development } \\
\hline Developing economies & $\begin{array}{c}3.03 \%{ }^{* * *} \\
(19.05)\end{array}$ & 2346 & $\begin{array}{c}2.09 \%^{* * *} \\
(11.21)\end{array}$ & 2174 & $\begin{array}{c}1.11 \%{ }^{* * *} \\
(5.42)\end{array}$ & 1188 \\
\hline Developed economies & $\begin{array}{c}3.42 \%{ }^{* * *} \\
(27.07)\end{array}$ & 7154 & $\begin{array}{c}1.76 \%{ }^{* * *} \\
(15.42) \\
\end{array}$ & 5758 & $\begin{array}{c}1.23 \%{ }^{* * *} \\
(19.26) \\
\end{array}$ & 5643 \\
\hline \multicolumn{7}{|c|}{ Panel D: Target ownership } \\
\hline Public & $\begin{array}{c}1.41 \%{ }^{* * *} \\
(7.58)\end{array}$ & 1434 & $\begin{array}{c}1.09 \%{ }^{* * *} \\
(5.73)\end{array}$ & 1347 & $\begin{array}{c}0.46 \%{ }^{* * *} \\
(3.77)\end{array}$ & 1359 \\
\hline Private & $\begin{array}{c}4.04 \%{ }^{* * *} \\
(23.41)\end{array}$ & 4520 & $\begin{array}{c}2.70 \%{ }^{* * *} \\
(19.58)\end{array}$ & 3480 & $\begin{array}{c}1.29 \%{ }^{* * * *} \\
(14.52)\end{array}$ & 3257 \\
\hline Subsidiary & $\begin{array}{c}3.06 \%{ }^{* * *} \\
(20.74) \\
\end{array}$ & 3546 & $\begin{array}{c}2.37 \%^{* * *} \\
(16.97) \\
\end{array}$ & 2890 & $\begin{array}{c}1.52 \%{ }^{* * *} \\
(13.55)\end{array}$ & 2430 \\
\hline \multicolumn{7}{|c|}{ Panel E: Payment method } \\
\hline Pure cash & $\begin{array}{l}2.08 \% \\
(21.55)\end{array}$ & 5420 & $\begin{array}{l}1.77 \%{ }^{* * *} \\
(19.56)\end{array}$ & 5064 & $\begin{array}{c}1.09 \%{ }^{* * *} \\
(18.01)\end{array}$ & 5454 \\
\hline Pure stock & $\begin{array}{c}4.75 \%{ }^{* * *} \\
(16.99)\end{array}$ & 2255 & $\begin{array}{c}3.03 \%{ }^{* * *} \\
(10.76)\end{array}$ & 1262 & $\begin{array}{c}1.07 \%^{* * *} \\
(4.50)^{* * *}\end{array}$ & 697 \\
\hline Combination & $\begin{array}{l}5.02 \%^{* * *} \\
(17.54) \\
\end{array}$ & 1825 & $\begin{array}{c}3.51 \%{ }^{* * *} \\
(14.15)\end{array}$ & 1391 & $\begin{array}{c}2.04 \%^{* * *} \\
(8.23) \\
\end{array}$ & 895 \\
\hline
\end{tabular}

This table presents the analysis of 3-day CARs across deal order. In Panel A, acquisitions are grouped by time periods over 2000 2009, and 2010 - 2018. For Panel C, countries are organized using World Bank classifications. In Panel E, cash offers include cash only and mixtures of cash and debt, stock offers include common stock only or a combination of common stock and options, warrants, or rights, and mixed deals are comprised of some proportion of cash and stock. $t$-statistics are reported in parentheses. ${ }^{*}, * *, * * *$ represent significance at the $1 \%, 5 \%$ and $10 \%$ level, respectively. 
Table A.4. Univariate analysis of 3-day cumulative abnormal returns by deal order and temporal interval Panel A: Deal order

\begin{tabular}{|c|c|c|c|c|c|c|}
\hline & \multicolumn{2}{|c|}{ Infrequent } & \multicolumn{2}{|c|}{ Frequent } & \multicolumn{2}{|c|}{ Highly Frequent } \\
\hline & CAR[-1,+1] & $N$ & CAR $[-1,+1]$ & $N$ & CAR[-1,+1] & $N$ \\
\hline $1^{\mathrm{st}}$ & $\begin{array}{c}3.64 \% \\
(22.23)\end{array}$ & 4638 & $\begin{array}{c}3.04 \% \\
(19.88)\end{array}$ & 3610 & $\begin{array}{c}2.60 \% \\
(11.69)\end{array}$ & 1252 \\
\hline $2^{\text {nd }}-3^{\text {rd }}$ & & & $\begin{array}{c}2.45 \% \\
(21.34)\end{array}$ & 5213 & $\begin{array}{c}1.95 \%{ }^{* * *} \\
(15.45)\end{array}$ & 2504 \\
\hline$>=4^{\text {th }}$ & & & $\begin{array}{c}1.48 \% \\
(5.02)\end{array}$ & 571 & $\begin{array}{c}1.18 \% \\
(19.30)\end{array}$ & 6475 \\
\hline
\end{tabular}

Panel B: Temporal interval

\begin{tabular}{|c|c|c|c|c|c|c|c|c|}
\hline & \multicolumn{2}{|c|}{ Overall } & \multicolumn{2}{|c|}{$1^{\text {st }}-2^{\text {nd }}$} & \multicolumn{2}{|c|}{$2^{\text {nd }}-3^{r d}$} & \multicolumn{2}{|l|}{$>=4^{\text {th }}$} \\
\hline & CAR $[-1,+1]$ & $N$ & CAR $[-1,+1]$ & $N$ & CAR $[-1,+1]$ & $N$ & CAR $[-1,+1]$ & $N$ \\
\hline$<$ one year & $\begin{array}{l}1.57 \%{ }^{* * *} \\
(24.33)\end{array}$ & 8701 & $\begin{array}{l}2.42 \% \\
(15.13)\end{array}$ & 2311 & $\begin{array}{l}1.89 \%^{* * *} \\
(11.42)\end{array}$ & 1554 & $\begin{array}{l}1.06 \%{ }^{* * *} \\
(15.50)\end{array}$ & 4836 \\
\hline one to two year(s) & $\begin{array}{l}1.91 \% \\
(12.94)\end{array}$ & 2023 & $\begin{array}{l}2.67 \% \%^{* * *} \\
(7.82)\end{array}$ & 665 & $\begin{array}{l}1.96 \% \%^{* * *} \\
(4.74)\end{array}$ & 448 & $\begin{array}{l}1.20 \% \\
(6.52)\end{array}$ & 910 \\
\hline$>$ two years & $\begin{array}{l}3.05 \%{ }^{* * *} \\
(35.08)\end{array}$ & 12373 & $\begin{array}{l}2.91 \%{ }^{* * *} \\
(14.70)\end{array}$ & 1886 & $\begin{array}{l}2.25 \%^{* * *} \\
(9.38)\end{array}$ & 853 & $\begin{array}{l}1.86 \% \\
(11.11)\end{array}$ & 1300 \\
\hline
\end{tabular}

This table presents the analysis of 3 -day CARs across deal order. $t$-statistics are reported in parentheses. $*, * *, * * *$ represent significance at the $1 \%, 5 \%$ and $10 \%$ level, respectively. 
Table A.5. Cross sectional regression analysis of 3-day cumulative abnormal returns

\begin{tabular}{|c|c|c|c|c|c|c|}
\hline Dependent variables & (1) & $(2)$ & (3) & $(4)$ & $(5)$ & $(6)$ \\
\hline Private & $\begin{array}{c}0.0151^{* * *} \\
(9.98)\end{array}$ & $\begin{array}{c}0.0098^{* * *} \\
(6.33)\end{array}$ & $\begin{array}{c}0.0098^{* * *} \\
(6.33)\end{array}$ & $\begin{array}{c}0.0159^{* * *} \\
(10.51)\end{array}$ & $\begin{array}{c}0.0099^{* * * *} \\
(6.36)\end{array}$ & $\begin{array}{c}0.0097^{* * * *} \\
(6.23)\end{array}$ \\
\hline Subsidiary & $\begin{array}{c}0.0142^{* * *} \\
(9.26)\end{array}$ & $\begin{array}{c}0.0110^{* * * *} \\
(7.05)\end{array}$ & $\begin{array}{c}0.0110^{* * *} \\
(7.05)\end{array}$ & $\begin{array}{c}0.0146^{* * *} \\
(9.55)\end{array}$ & $\begin{array}{c}0.0108^{* * * *} \\
(6.95)\end{array}$ & $\begin{array}{c}0.0107^{* * * *} \\
(6.88)\end{array}$ \\
\hline Cash & $\begin{array}{c}-0.0170^{* * *} \\
(-11.47)\end{array}$ & $\begin{array}{c}-0.0116^{* * *} \\
(-6.81)\end{array}$ & $\begin{array}{c}-0.0116^{* * *} \\
(-6.82)\end{array}$ & $\begin{array}{c}-0.0178^{* * *} \\
(-12.01)\end{array}$ & $\begin{array}{c}-0.0117^{* * *} \\
(-6.88)\end{array}$ & $\begin{array}{c}-0.0116^{* * *} \\
(-6.84)\end{array}$ \\
\hline Hybrid & $\begin{array}{c}-0.0021 \\
(-1.18)\end{array}$ & $\begin{array}{c}-0.0004 \\
(-0.20)\end{array}$ & $\begin{array}{c}-0.0004 \\
(-0.20)\end{array}$ & $\begin{array}{c}-0.0030^{*} \\
(-1.70)\end{array}$ & $\begin{array}{c}-0.0009 \\
(-0.45)\end{array}$ & $\begin{array}{c}-0.0009 \\
(-0.45)\end{array}$ \\
\hline Cross-country & $\begin{array}{c}0.0004 \\
(0.34)\end{array}$ & $\begin{array}{c}-0.0022^{*} \\
(-1.77)\end{array}$ & $\begin{array}{c}-0.0022^{*} \\
(-1.76)\end{array}$ & $\begin{array}{c}0.0006 \\
(0.46)\end{array}$ & $\begin{array}{c}-0.0021^{*} \\
(-1.65)\end{array}$ & $\begin{array}{c}-0.0020 \\
(-1.60)\end{array}$ \\
\hline Relatedness & $\begin{array}{c}-0.0010 \\
(-0.94)\end{array}$ & $\begin{array}{c}0.0003 \\
(0.30)\end{array}$ & $\begin{array}{c}0.0003 \\
(0.30)\end{array}$ & $\begin{array}{c}-0.0014 \\
(-1.23)\end{array}$ & $\begin{array}{c}0.0000 \\
(0.03)\end{array}$ & $\begin{array}{c}0.0000 \\
(0.04)\end{array}$ \\
\hline Relative size & $\begin{array}{c}0.0070^{* * *} \\
(12.50)\end{array}$ & $\begin{array}{c}0.0068^{* * * *} \\
(8.81)\end{array}$ & $\begin{array}{c}0.0068^{* * * *} \\
(8.81)\end{array}$ & $\begin{array}{c}0.0074^{* * *} \\
(13.43)\end{array}$ & $\begin{array}{c}0.0069^{* * *} \\
(8.97)\end{array}$ & $\begin{array}{c}0.0069^{* * * *} \\
(8.97)\end{array}$ \\
\hline Time interval & & $\begin{array}{c}0.0007^{* * * *} \\
(3.34)\end{array}$ & $\begin{array}{c}0.0007^{* * *} \\
(2.61)\end{array}$ & & $\begin{array}{c}0.0006^{* * *} \\
(3.17)\end{array}$ & $\begin{array}{c}0.0012^{* * *} \\
(3.95)\end{array}$ \\
\hline Frequent & $\begin{array}{c}-0.0071^{* * *} \\
(-5.00)\end{array}$ & & & & & \\
\hline Highly frequent & $\begin{array}{c}-0.0146^{* * *} \\
(-9.62)\end{array}$ & $\begin{array}{c}-0.0065^{* * *} \\
(-5.38)\end{array}$ & $\begin{array}{c}-0.0066^{* * *} \\
(-4.46)\end{array}$ & & & \\
\hline Highly frequent ${ }^{*}$ Time interval & & & $\begin{array}{r}0.0001 \\
(0.15)\end{array}$ & & & \\
\hline No. of deals & & & & $\begin{array}{c}-0.0010^{* * *} \\
(-8.83)\end{array}$ & $\begin{array}{c}-0.0007^{* * *} \\
(-6.49)\end{array}$ & $\begin{array}{c}-0.0006^{* * *} \\
(-4.95)\end{array}$ \\
\hline No. of deals ${ }^{*}$ Time interval & & & & & & $\begin{array}{c}0.0002 \\
(0.46)\end{array}$ \\
\hline Constant & $\begin{array}{c}0.0334 \\
(1.55)\end{array}$ & $\begin{array}{c}0.0361 \\
(1.46)\end{array}$ & $\begin{array}{c}0.0363 \\
(1.47)\end{array}$ & $\begin{array}{c}0.0233 \\
(1.08)\end{array}$ & $\begin{array}{c}0.0307 \\
(1.24)\end{array}$ & $\begin{array}{c}0.0301 \\
(1.22)\end{array}$ \\
\hline Country dummy & Y & Y & $\mathrm{Y}$ & Y & $\mathrm{Y}$ & $\mathrm{Y}$ \\
\hline Industrial dummy & Y & $\mathrm{Y}$ & Y & $\mathrm{Y}$ & Y & $\mathrm{Y}$ \\
\hline Year dummy & Y & Y & $\mathrm{Y}$ & $\mathrm{Y}$ & $\mathrm{Y}$ & $\mathrm{Y}$ \\
\hline Observations & 24263 & 14763 & 14763 & 24263 & 14763 & 14763 \\
\hline$F$-statistic & 13.71 & 7.65 & 7.57 & 13.66 & 7.81 & 7.79 \\
\hline Adjusted $R^{2}$ & $5.26 \%$ & $3.90 \%$ & $3.89 \%$ & $5.19 \%$ & $3.98 \%$ & $4.02 \%$ \\
\hline
\end{tabular}

The table presents ordinary least square regressions of the bidder's 3-day cumulative abnormal returns. Frequent or Highly frequent takes the value one if the acquirer made two to four or more deals over the sample period, respectively. No. of deals is number of acquisition made by acquirers. Time interval counts number of years between deals. Private and Subsidiary equal to one if the target is a private company or a subsidiary, respectively. Cash and Hybrid indicate if targets are acquired by cash or mix of cash and stock. Cross country and Relatedness take one if acquirer and target come from same geographic region and industry, respectively. Relative size computed as the natural log of target deal value divided by acquirer market value as of one month before the announcement date. Four-digit SIC code, country and year dummies are included in each model. $t$-statistics are reported in parentheses. *,**, *** represent significance at the $1 \%, 5 \%$ and $10 \%$ level, respectively. 
Table A.6. Cross sectional regression analysis of 5-day cumulative abnormal returns - excluding US deals

\begin{tabular}{|c|c|c|c|c|c|c|}
\hline Dependent variables & $(1)$ & $(2)$ & $(3)$ & $(4)$ & $(5)$ & $(6)$ \\
\hline Private & $\begin{array}{c}0.0172 \\
(7.92)\end{array}$ & $\begin{array}{c}0.0115 \\
(4.87)\end{array}$ & $\begin{array}{c}0.0115 \\
(4.87)\end{array}$ & $\begin{array}{c}0.0172^{*} \\
(7.93)\end{array}$ & $\begin{array}{c}0.0110 \\
(4.66)\end{array}$ & $\begin{array}{c}0.0109^{3 \ldots \pi} \\
(4.62)\end{array}$ \\
\hline Subsidiary & $\begin{array}{c}0.0146^{* * * *} \\
(6.81)\end{array}$ & $\begin{array}{c}0.0105^{* * *} \\
(4.52)\end{array}$ & $\begin{array}{c}0.0105^{* * *} \\
(4.52)\end{array}$ & $\begin{array}{c}0.0146^{* * * *} \\
(6.80)\end{array}$ & $\begin{array}{c}0.0101^{* * * *} \\
(4.33)\end{array}$ & $\begin{array}{c}0.0100^{* * *} \\
(4.30)\end{array}$ \\
\hline Cash & $\begin{array}{c}-0.0179^{* * *} \\
(-9.18)\end{array}$ & $\begin{array}{c}-0.0138^{* * *} \\
(-6.02)\end{array}$ & $\begin{array}{c}-0.0138^{* * *} \\
(-6.03)\end{array}$ & $\begin{array}{c}-0.0180^{* * *} \\
(-9.24)\end{array}$ & $\begin{array}{c}-0.0136^{* * *} \\
(-5.96)\end{array}$ & $\begin{array}{c}-0.0136^{* * *} \\
(-5.94)\end{array}$ \\
\hline Hybrid & $\begin{array}{c}0.0006 \\
(0.24)\end{array}$ & $\begin{array}{c}-0.0012 \\
(-0.42)\end{array}$ & $\begin{array}{c}-0.0012 \\
(-0.42)\end{array}$ & $\begin{array}{c}-0.0001 \\
(-0.03)\end{array}$ & $\begin{array}{c}-0.0018 \\
(-0.61)\end{array}$ & $\begin{array}{c}-0.0018 \\
(-0.61)\end{array}$ \\
\hline Cross-country & $\begin{array}{c}0.0008 \\
(0.48)\end{array}$ & $\begin{array}{c}-0.0010 \\
(-0.56)\end{array}$ & $\begin{array}{c}-0.0010 \\
(-0.55)\end{array}$ & $\begin{array}{c}0.0014 \\
(0.85)\end{array}$ & $\begin{array}{c}-0.0003 \\
(-0.14)\end{array}$ & $\begin{array}{c}-0.0002 \\
(-0.12)\end{array}$ \\
\hline Relatedness & $\begin{array}{c}-0.0017 \\
(-1.10)\end{array}$ & $\begin{array}{c}-0.0006 \\
(-0.36)\end{array}$ & $\begin{array}{c}-0.0006 \\
(-0.36)\end{array}$ & $\begin{array}{c}-0.0019 \\
(-1.23)\end{array}$ & $\begin{array}{c}-0.0009 \\
(-0.51)\end{array}$ & $\begin{array}{c}-0.0009 \\
(-0.51)\end{array}$ \\
\hline Relative size & $\begin{array}{c}0.0053^{* * *} \\
(6.59)\end{array}$ & $\begin{array}{c}0.0041^{* * *} \\
(3.50)\end{array}$ & $\begin{array}{c}0.0041^{* * *} \\
(3.50)\end{array}$ & $\begin{array}{c}0.0055^{* * *} \\
(6.86)\end{array}$ & $\begin{array}{c}0.0042^{* * *} \\
(3.59)\end{array}$ & $\begin{array}{c}0.0042^{* * *} \\
(3.59)\end{array}$ \\
\hline Time interval & & $\begin{array}{c}0.0003^{* * * *} \\
(3.44)\end{array}$ & $\begin{array}{c}0.0003^{* * *} \\
(2.68)\end{array}$ & & $\begin{array}{c}0.0002^{* * *} \\
(3.22)\end{array}$ & $\begin{array}{c}0.0006^{* * *} \\
(3.66)\end{array}$ \\
\hline Frequent & $\begin{array}{c}-0.0052^{* * *} \\
(-2.81)\end{array}$ & & & & & \\
\hline Highly frequent & $\begin{array}{c}-0.0133^{* * *} \\
(-6.48)\end{array}$ & $\begin{array}{c}-0.0078^{* * *} \\
(-4.51)\end{array}$ & $\begin{array}{c}-0.0084^{* * *} \\
(-4.00)\end{array}$ & & & \\
\hline Highly frequent ${ }^{*}$ Time interval & & & $\begin{array}{c}0.0003 \\
(0.50)\end{array}$ & & & \\
\hline No. of deals & & & & $\begin{array}{c}-0.0017^{* * *} \\
(-8.26)\end{array}$ & $\begin{array}{c}-0.0013^{* * *} \\
(-6.71)\end{array}$ & $\begin{array}{c}-0.0012^{* * *} \\
(-5.60)\end{array}$ \\
\hline No. of deals ${ }^{*}$ Time interval & & & & & & $\begin{array}{c}0.0001 \\
(0.32)\end{array}$ \\
\hline Constant & $\begin{array}{c}0.0272 \\
(1.07)\end{array}$ & $\begin{array}{c}0.0287 \\
(0.95)\end{array}$ & $\begin{array}{c}0.0293 \\
(0.97)\end{array}$ & $\begin{array}{c}0.0177 \\
(0.69)\end{array}$ & $\begin{array}{c}0.0211 \\
(0.70)\end{array}$ & $\begin{array}{c}0.0208 \\
(0.69)\end{array}$ \\
\hline Country dummy & Y & Y & Y & Y & Y & Y \\
\hline Industrial dummy & Y & Y & Y & Y & Y & $\mathrm{Y}$ \\
\hline Year dummy & Y & Y & Y & Y & Y & Y \\
\hline Observations & 17558 & 10027 & 10027 & 17558 & 10027 & 10027 \\
\hline$F$-statistic & 10.20 & 5.44 & 5.38 & 10.54 & 5.73 & 4.03 \\
\hline Adjusted $R^{2}$ & $5.22 \%$ & $3.79 \%$ & $3.78 \%$ & $5.35 \%$ & $4.03 \%$ & $5.22 \%$ \\
\hline \multicolumn{7}{|c|}{$\begin{array}{l}\text { The table presents ordinary least square regressions of the bidder's 5-day cumulative abnormal returns based on a sub-sample } \\
\text { excluding US deals. Frequent or Highly frequent takes the value one if the acquirer made two to four or more deals over the sample } \\
\text { period, respectively. No. of deals is number of acquisition made by acquirers. Time interval counts number of years between deals. } \\
\text { Private and Subsidiary equal to one if the target is a private company or a subsidiary, respectively. Cash and Hybrid indicate if } \\
\text { targets are acquired by cash or mix of cash and stock. Cross country and Relatedness take one if acquirer and target come from same } \\
\text { geographic region and industry, respectively. Relative size computed as the natural log of target deal value divided by acquirer } \\
\text { market value as of one month before the announcement date. Four-digit SIC code, country and year dummies are included in each } \\
\text { model. } t \text {-statistics are reported in parentheses. }{ }^{*}, * *, * * \text { represent significance at the } 1 \%, 5 \% \text { and } 10 \% \text { level, respectively. }\end{array}$} \\
\hline
\end{tabular}


Figure 1. Mean of cumulative abnormal return and time interval between deals.

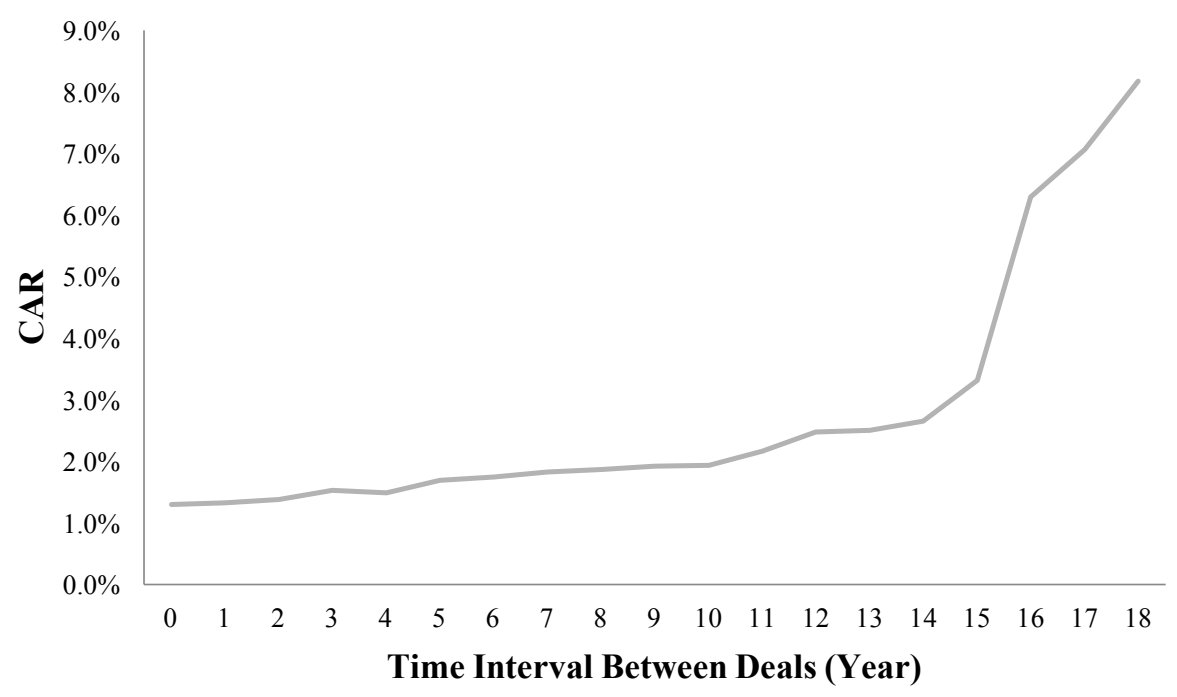




\begin{tabular}{|c|c|c|c|}
\hline \multicolumn{2}{|c|}{ Data Screen } & \multirow{2}{*}{$\begin{array}{c}\text { Sample Size } \\
204981\end{array}$} & \multirow{2}{*}{$\frac{\text { Sample Reduction }}{-}$} \\
\hline 1. & The acquisition was completed between $01 / 01 / 2000$ and $31 / 12 / 2018$. & & \\
\hline 2. & The target firm is either: public, private or subsidiary. & 199669 & 5312 \\
\hline 3 . & $\begin{array}{l}\text { The target firm was purchased at a disclosed dollar value of at least } \$ 1 \\
\text { million. }\end{array}$ & 105557 & 94112 \\
\hline 4. & $\begin{array}{l}\text { The bidder owned either nothing or less than } 50 \% \text { percent of the target's } \\
\text { voting rights before the acquisition. The transfer of the control rights to } \\
\text { the acquirer was at least } 50 \% \text { of shares or ownership after takeover. }\end{array}$ & 83203 & 22354 \\
\hline 5 . & $\begin{array}{l}\text { Utilities (with a primary SIC code between } 4900 \text { and } 4999 \text { ) and financial } \\
\text { institutions (with a primary SIC code between } 6000 \text { and 6999) are not } \\
\text { included. }\end{array}$ & 60025 & 23178 \\
\hline 6. & $\begin{array}{l}\text { Acquiring two or more targets during the event window period is regarded } \\
\text { as an extreme case for exclusion from the sample. }\end{array}$ & 41883 & 18142 \\
\hline 7. & $\begin{array}{l}\text { Deals completed more than } 1,000 \text { days after the announcement date are } \\
\text { removed. }\end{array}$ & 40602 & 1281 \\
\hline 8 . & $\begin{array}{l}\text { The acquiring firm is publicly traded on either a domestic or a foreign } \\
\text { stock exchange, which has three days }(-1,+1) \text { and five days }(-2,+2) \text { of } \\
\text { return data around the announcement of a takeover held on the } \\
\text { DataStream database. }\end{array}$ & 24263 & 16339 \\
\hline
\end{tabular}

The table presents sample select process. Merger and acquisition data were collected from the SDC database. Stock information was obtained from Datastream. 
Table 2. Takeover activity by country

\begin{tabular}{|c|c|c|c|c|c|c|c|c|c|c|c|c|}
\hline \multirow{2}{*}{ Country } & \multicolumn{3}{|c|}{ Infrequent } & \multicolumn{3}{|c|}{$\begin{array}{l}\text { Frequent } \\
\end{array}$} & \multicolumn{3}{|c|}{ Highly Frequent } & \multicolumn{3}{|c|}{ Overall } \\
\hline & Firm & Deal & Value & Firm & Deal & Value & Firm & Deal & Value & Firm & Deal & Value \\
\hline Anguilla & 1 & 1 & 18.9 & - & - & - & - & - & - & 1 & 1 & 18.9 \\
\hline Argentina & 6 & 6 & 7.3 & 3 & 7 & 2.0 & - & - & - & 9 & 13 & 9.2 \\
\hline Australia & 372 & 372 & 11.6 & 268 & 703 & 74.4 & 53 & 354 & 71.2 & 693 & 1429 & 157.2 \\
\hline Austria & 3 & 3 & 923.2 & 1 & 2 & 35.0 & - & - & - & 4 & 5 & 958.2 \\
\hline Bahamas & - & - & - & 1 & 2 & 744.3 & - & - & - & 1 & 2 & 744.3 \\
\hline Bahrain & 3 & 3 & 493.8 & - & - & - & - & - & - & 3 & 3 & 493.8 \\
\hline Belgium & 17 & 17 & 1.3 & 13 & 30 & 11.3 & 5 & 23 & 14.2 & 35 & 70 & 26.9 \\
\hline Bermuda & 9 & 9 & 8.5 & 5 & 11 & 2.5 & 2 & 24 & 16.1 & 16 & 44 & 27.0 \\
\hline Brazil & 15 & 15 & 3.6 & 13 & 34 & 22.6 & 5 & 39 & 18.8 & 33 & 88 & 45.0 \\
\hline British Virgin & - & - & - & 1 & 2 & 12.2 & - & - & - & 1 & 2 & 12.2 \\
\hline Bulgaria & 2 & 2 & 11.3 & - & - & - & - & - & - & 2 & 2 & 11.3 \\
\hline Canada & 467 & 467 & 24.9 & 322 & 812 & 137.2 & 94 & 658 & 172.2 & 883 & 1937 & 334.3 \\
\hline Cayman Is. & 2 & 2 & 37.5 & 1 & 2 & 103.9 & 1 & 3 & 229.1 & 4 & 7 & 370.5 \\
\hline Chile & 11 & 11 & 454.9 & 6 & 14 & 6.7 & - & - & - & 17 & 25 & 7.2 \\
\hline China & 1041 & 1041 & 245.5 & 763 & 1945 & 360.6 & 87 & 528 & 55.5 & 1891 & 3514 & 661.6 \\
\hline Colombia & 2 & 2 & 342.0 & 4 & 10 & 1.6 & 1 & 10 & 1.4 & 7 & 22 & 3.3 \\
\hline Croatia & 1 & 1 & 2.3 & - & - & - & - & - & - & 1 & 1 & 2.3 \\
\hline Cyprus & 1 & 1 & 1.9 & 3 & 5 & 147.9 & - & - & - & 4 & 6 & 149.8 \\
\hline Denmark & 18 & 18 & 1.7 & 16 & 47 & 22.4 & 2 & 11 & 716.0 & 36 & 76 & 24.8 \\
\hline Egypt & 3 & 3 & 724.2 & 1 & 2 & 62.9 & - & - & - & 4 & 5 & 787.2 \\
\hline Estonia & 1 & 1 & 74.1 & - & - & - & - & - & - & 1 & 1 & 74.1 \\
\hline Faroe Is. & 1 & 1 & 12.7 & 1 & 2 & 217.0 & - & - & - & 2 & 3 & 229.7 \\
\hline Finland & 21 & 21 & 4.7 & 23 & 56 & 6.1 & 12 & 90 & 27.4 & 56 & 167 & 38.3 \\
\hline France & 62 & 62 & 13.1 & 58 & 144 & 30.3 & 31 & 218 & 267.3 & 151 & 424 & 310.7 \\
\hline Gabon & 1 & 1 & 40.0 & - & - & - & - & - & - & 1 & 1 & 40.0 \\
\hline Germany & 51 & 51 & 14.6 & 44 & 114 & 57.0 & 18 & 114 & 220.8 & 113 & 279 & 292.3 \\
\hline Gibraltar & 1 & 1 & 23.5 & 1 & 2 & 138.7 & - & - & - & 2 & 3 & 162.2 \\
\hline Greece & 17 & 17 & 5.7 & 5 & 11 & 1.7 & - & - & - & 22 & 28 & 7.4 \\
\hline Guernsey & 2 & 2 & 7.9 & - & - & - & - & - & - & 2 & 2 & 7.9 \\
\hline Hungary & 2 & 2 & 46.2 & 1 & 2 & 796.9 & - & - & - & 3 & 4 & 843.1 \\
\hline Iceland & 2 & 2 & 1.0 & - & - & - & - & - & - & 2 & 2 & 1.0 \\
\hline India & 147 & 147 & 17.4 & 67 & 160 & 17.6 & 16 & 107 & 20.3 & 230 & 414 & 55.4 \\
\hline Indonesia & 23 & 23 & 1.8 & 7 & 14 & 948.4 & - & 148 & 31.1 & 30 & 37 & 2.8 \\
\hline Ireland & 10 & 10 & 1.1 & 12 & 28 & 9.3 & 17 & 12 & 1.2 & 39 & 186 & 41.5 \\
\hline Isle of Man & - & - & - & 1 & 3 & 1.7 & 1 & 95 & 11.4 & 2 & 15 & 2.9 \\
\hline Israel & 14 & 14 & 513.0 & 14 & 34 & 3.0 & - & - & - & 28 & 48 & 3.5 \\
\hline Italy & 31 & 31 & 2.7 & 24 & 59 & 30.8 & 13 & 1157 & 217.2 & 68 & 185 & 44.9 \\
\hline Japan & 566 & 566 & 35.9 & 490 & 1267 & 132.0 & 148 & 1 & 2.1 & 1204 & 2990 & 385.0 \\
\hline Jersey & 5 & 5 & 25.5 & 2 & 7 & 527.2 & 1 & 18 & 7.0 & 8 & 13 & 554.8 \\
\hline
\end{tabular}

This table presents number of acquirers, number of deals and transaction value of deals for 81 countries over the period $01 / 01 / 2000$ - 31/12/2018, based on frequency of acquisition. Numbers marked in bold are scaled in million US Dollars, otherwise billion US Dollars. The final row of the table contains the total number of observations in the sample. An infrequent, frequent or highly frequent acquirer refers to a firm that has acquired only one, two to four, or five and more targets over the sample period, respectively. 
Table 2. Takeover activity by country - continued

\begin{tabular}{|c|c|c|c|c|c|c|c|c|c|c|c|c|}
\hline \multirow{2}{*}{ Country } & \multicolumn{3}{|c|}{ Infrequent } & \multicolumn{3}{|c|}{ Frequent } & \multicolumn{3}{|c|}{ Highly frequent } & \multicolumn{3}{|c|}{ All } \\
\hline & Firm & Deal & Value & Firm & Deal & Value & Firm & Deal & Value & Firm & Deal & Value \\
\hline Jordan & 3 & 3 & 31.2 & - & - & - & - & - & - & 3 & 3 & 31.2 \\
\hline Kazakhstan & - & - & - & 2 & 2 & 39.9 & - & - & - & 2 & 2 & 39.9 \\
\hline Kenya & 2 & 2 & 63.0 & - & - & - & - & - & - & 2 & 2 & 63.0 \\
\hline Kuwait & 3 & 3 & 61.1 & 1 & 3 & 23.9 & - & - & - & 4 & 6 & 85.1 \\
\hline Luxembourg & 4 & 4 & 122.7 & 7 & 21 & 162.0 & 1 & 56 & 1.7 & 12 & 43 & 169.1 \\
\hline Malaysia & 127 & 127 & 5.1 & 70 & 181 & 10.7 & 8 & 6 & 470.9 & 205 & 364 & 17.4 \\
\hline Malta & - & - & - & 1 & 4 & 37.9 & 1 & 94 & 53.6 & 2 & 10 & 508.8 \\
\hline Mexico & 1 & 1 & 57.2 & - & - & - & - & - & - & 1 & 1 & 57.2 \\
\hline Monaco & 2 & 2 & 690.6 & 1 & 3 & 791.0 & - & - & - & 3 & 5 & 1.5 \\
\hline Morocco & 1 & 1 & 83.4 & 1 & 2 & 434.9 & - & - & - & 2 & 3 & 518.4 \\
\hline Myanmar & 1 & 1 & 8.2 & - & - & - & - & - & - & 1 & 1 & 8.2 \\
\hline Nethntilles & - & - & - & 1 & 4 & 506.1 & - & - & - & 1 & 4 & 506.1 \\
\hline Netherlands & 13 & 13 & 4.8 & 22 & 61 & 62.7 & 9 & 92 & 63.0 & 44 & 168 & 121.2 \\
\hline New Zealand & 21 & 21 & 1.1 & 15 & 42 & 1.7 & - & - & - & 36 & 63 & 2.8 \\
\hline Nigeria & 1 & 1 & 40.2 & - & - & - & - & - & - & 1 & 1 & 40.2 \\
\hline Norway & 29 & 29 & 3.7 & 14 & 41 & 2.8 & 13 & 24 & 4.7 & 56 & 162 & 69.5 \\
\hline Pakistan & 3 & 3 & 20.3 & 2 & 4 & 328.7 & - & - & - & 5 & 7 & 349.0 \\
\hline Peru & 5 & 5 & 145.8 & 3 & 7 & 1.0 & - & - & - & 8 & 12 & 1.2 \\
\hline Poland & 51 & 51 & 1.4 & 31 & 79 & 6.0 & 4 & 11 & 6.8 & 86 & 154 & 12.0 \\
\hline Portugal & 6 & 6 & 1.6 & 6 & 13 & 1.7 & - & - & - & 12 & 19 & 3.4 \\
\hline Qatar & 4 & 4 & 197.9 & - & - & - & 2 & 7 & 1.2 & 6 & 15 & 7.0 \\
\hline Romania & 3 & 3 & 163.8 & - & - & - & - & - & - & 3 & 3 & 163.8 \\
\hline Russian Fed & 2 & 2 & 49.6 & - & - & - & 1 & 80 & 7.0 & 3 & 9 & 1.2 \\
\hline Saudi Arabia & 14 & 14 & 499.8 & 5 & 11 & 16.6 & - & - & - & 19 & 25 & 17.1 \\
\hline Singapore & 91 & 91 & 5.2 & 59 & 156 & 3.4 & 11 & 49 & 15.0 & 161 & 327 & 15.7 \\
\hline Slovenia & 2 & 2 & 19.7 & 1 & 2 & 8.0 & - & - & - & 3 & 4 & 27.7 \\
\hline South Africa & 42 & 42 & 6.4 & 32 & 81 & 19.0 & 8 & 122 & 21.8 & 82 & 172 & 40.5 \\
\hline South Korea & 154 & 154 & 11.9 & 87 & 221 & 28.5 & 20 & 57 & 46.3 & 261 & 497 & 62.2 \\
\hline Spain & 26 & 26 & 6.9 & 21 & 52 & 13.0 & 8 & - & - & 55 & 135 & 66.3 \\
\hline Sweden & 82 & 82 & 3.2 & 80 & 220 & 30.0 & 33 & 247 & 57.9 & 195 & 549 & 91.1 \\
\hline Switzerland & 29 & 29 & 6.5 & 25 & 72 & 51.3 & 12 & 99 & 284.4 & 66 & 200 & 342.2 \\
\hline Thailand & 34 & 34 & 5.9 & 13 & 33 & 9.3 & 1 & 9 & 246.7 & 48 & 76 & 15.5 \\
\hline Tunisia & 1 & 1 & 18.0 & - & - & - & - & - & - & 1 & 1 & 18.0 \\
\hline Turkey & 21 & 21 & 1.9 & 13 & 30 & 2.0 & - & - & - & 34 & 51 & 3.9 \\
\hline US Virgin Is & - & - & - & 1 & 2 & 214.1 & - & - & - & 1 & 2 & 214.1 \\
\hline Ukraine & 1 & 1 & 155.0 & 1 & 1 & 13.3 & - & - & - & 2 & 2 & 168.3 \\
\hline UK & 166 & 166 & 28.6 & 210 & 589 & 124.2 & 175 & 1744 & 491.8 & 551 & 2499 & 644.6 \\
\hline USA & 757 & 757 & 191.7 & 710 & 1917 & 904.9 & 438 & 3924 & 3383.4 & 1905 & 6596 & 4480.1 \\
\hline Uruguay & - & - & - & 1 & 2 & 10.3 & - & - & - & 1 & 2 & 10.3 \\
\hline Utd. Arab Em. & 4 & 4 & 1.2 & 2 & 5 & 6.0 & - & - & - & 6 & 9 & 7.2 \\
\hline Venezuela & - & - & - & 1 & 2 & 36.2 & - & - & - & 1 & 2 & 36.2 \\
\hline Zambia & 1 & 1 & 2.5 & - & - & - & - & - & - & 1 & 1 & 2.5 \\
\hline Total & 4638 & 4638 & 695.8 & 3610 & 9394 & 2393.9 & 1252 & 10231 & 5593.4 & 9500 & 24263 & 8683.2 \\
\hline
\end{tabular}

This table presents number of acquirers, number of deals and transaction value of deals for 81 countries over the period 01/01/2000 $31 / 12 / 2018$, based on frequency of acquisition. Numbers marked in bold are scaled in million US Dollars, otherwise billion US Dollars. The final row of the table contains the total number of observations in the sample. An infrequent, frequent or highly frequent acquirer refers to a firm that has acquired only one, two to four, or five and more targets over the sample period, respectively. 
Table 3. Takeover activity by target type payment method transnational attribute and industrial relatedness

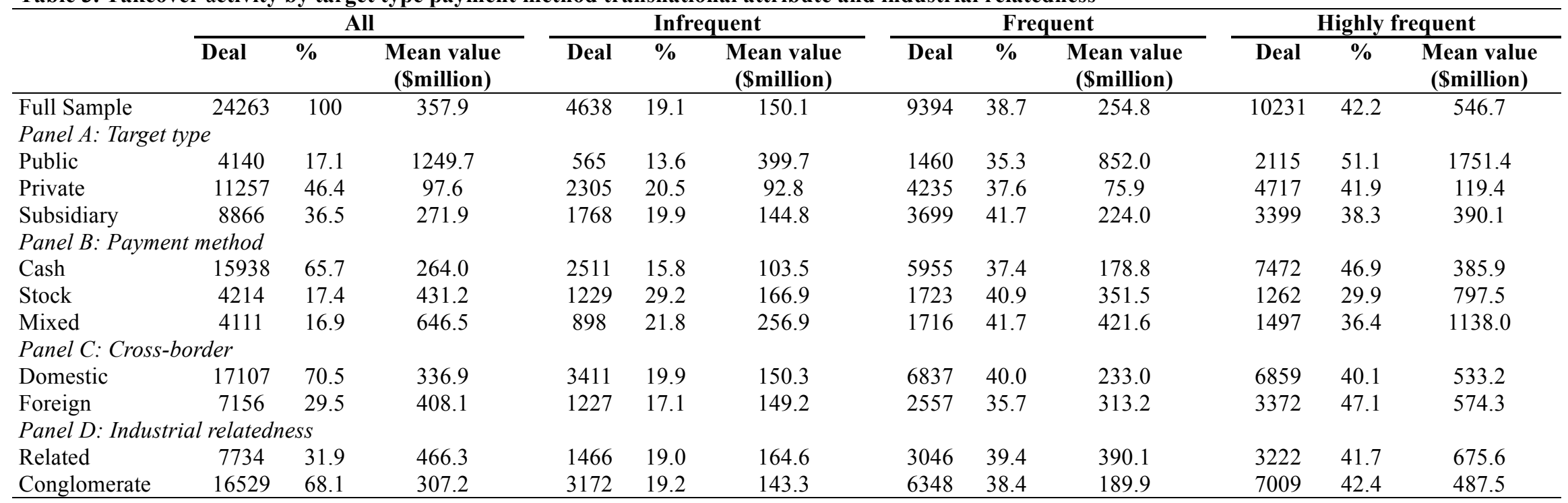

This table presents summary statistics of the sample according to four categories. The target type is private, public or subsidiary. The method of payment is pure cash, pure equity or mixed. Cash offers include cash only and mixtures of cash and debt. Stock offers include common stock only or a combination of common stock and options, warrants, or rights. Mixed deals are comprised of some proportion of cash and stock. The results for each panel are divided further by merger frequency. Percentages in 'All' column are computed by dividing the deal counts for an individual row by the total number of deals. For the rest of the rows, percentages display the proportion of deals in a column category from among those in the row. $t$-statistics are reported in parentheses. ${ }^{*}, * * * * *$ represent significance at the $1 \%, 5 \%$ and $10 \%$ level, respectively. 
Table 4. Univariate analysis of cumulative abnormal returns by $M \& A$ frequency

\begin{tabular}{|c|c|c|c|c|c|c|}
\hline & \multicolumn{2}{|c|}{ Infrequent } & \multicolumn{2}{|c|}{ Frequent } & \multicolumn{2}{|c|}{ Highly frequent } \\
\hline & CAR $[-2,+2]$ & $N$ & CAR $[-2,+2]$ & $N$ & CAR[-2,+2] & $N$ \\
\hline \multicolumn{7}{|c|}{ Panel A: Time span of observation } \\
\hline Within one year & $\begin{array}{c}2.61 \% \\
(30.93)\end{array}$ & 16343 & $\begin{array}{l}1.73 \% \\
(17.61)\end{array}$ & 7231 & $\begin{array}{c}1.64 \% \\
(6.56)\end{array}$ & 689 \\
\hline Within five years & $\begin{array}{c}3.87 \%{ }^{* * *} \\
(24.45)\end{array}$ & 5972 & $\begin{array}{c}2.77 \%^{* * *} \\
(32.37)\end{array}$ & 11525 & $\begin{array}{c}1.68 \%{ }^{* * *} \\
(21.50)\end{array}$ & 6766 \\
\hline Within ten years & $\begin{array}{c}4.00 \%{ }^{* * *} \\
(22.83)\end{array}$ & 5022 & $\begin{array}{c}3.01 \%{ }^{* * * *} \\
(31.29)\end{array}$ & 10333 & $\begin{array}{c}1.71 \%{ }^{* * *} \\
(24.62)\end{array}$ & 8908 \\
\hline Within fifteen years & $\begin{array}{c}4.08 \%{ }^{* * *} \\
(22.15)\end{array}$ & 4686 & $\begin{array}{c}3.05 \%{ }^{* * * *} \\
(30.19)\end{array}$ & 9691 & $\begin{array}{c}1.80 \%{ }^{* * * *} \\
(26.71)\end{array}$ & 9886 \\
\hline Within sample span & $\begin{array}{c}4.10 \%{ }^{* * *} \\
(22.07) \\
\end{array}$ & 4638 & $\begin{array}{c}3.08 \%{ }^{* * * *} \\
(29.79) \\
\end{array}$ & 9394 & $\begin{array}{c}1.81 \%{ }^{* * * *} \\
(27.27) \\
\end{array}$ & 10231 \\
\hline \multicolumn{7}{|l|}{ Panel B:Relative size } \\
\hline$<5 \%$ & $\begin{array}{c}1.09 \% \\
(5.53)\end{array}$ & 1401 & $\begin{array}{c}1.00 \% \\
(8.97)\end{array}$ & 3951 & $\begin{array}{l}0.85 \% \\
(12.08)\end{array}$ & 6197 \\
\hline$[5 \% 15 \%)$ & $\begin{array}{c}2.96 \%{ }^{* * *} \\
(10.50)\end{array}$ & 1076 & $\begin{array}{c}2.60 \% \%^{* * *} \\
(11.92)\end{array}$ & 2320 & $\begin{array}{c}2.46 \%{ }^{* * * *} \\
(16.41)\end{array}$ & 2189 \\
\hline$[15 \% 25 \%]$ & $\begin{array}{c}4.04 \%{ }^{* * *} \\
(6.80)^{* * *}\end{array}$ & 500 & $\begin{array}{c}3.82 \%{ }^{* * * *} \\
(10.12)\end{array}$ & 949 & $\begin{array}{c}2.95 \%{ }^{* * * *} \\
(9.97)\end{array}$ & 679 \\
\hline$>25 \%$ & $\begin{array}{c}6.93 \%{ }^{* * *} \\
(16.61)\end{array}$ & 1661 & $\begin{array}{c}4.36 \%{ }^{* * *} \\
(12.22)\end{array}$ & 2174 & $\begin{array}{c}3.86 \%{ }^{* * *} \\
(11.84)\end{array}$ & 1166 \\
\hline \multicolumn{7}{|l|}{ Panel C: Region } \\
\hline Asia & $\begin{array}{c}2.46 \% \\
(13.69)\end{array}$ & 2269 & $\begin{array}{c}2.38 \%{ }^{* * * *} \\
(15.24)\end{array}$ & 4116 & $\begin{array}{l}1.64 \% \\
(10.77)\end{array}$ & 2173 \\
\hline Europe & $\begin{array}{c}3.44 \% \%^{* * *} \\
(8.09)\end{array}$ & 647 & $\begin{array}{c}2.42 \%{ }^{* * *} \\
(11.83)\end{array}$ & 1593 & $\begin{array}{c}1.86 \%{ }^{* * * *} \\
(17.01)\end{array}$ & 2941 \\
\hline Americas & $\begin{array}{c}5.39 \%{ }^{* * *} \\
(12.07)^{* *}\end{array}$ & 1281 & $\begin{array}{c}2.19 \%^{* * *} \\
(8.83)\end{array}$ & 2853 & $\begin{array}{c}1.67 \%^{* * *} \\
(16.47)\end{array}$ & 4705 \\
\hline Africa & $\begin{array}{c}2.28 \%{ }^{* *} \\
(2.59)\end{array}$ & 49 & $\begin{array}{l}1.27 \% \\
(1.58)\end{array}$ & 87 & $\begin{array}{l}-0.42 \% \\
(-0.62)\end{array}$ & 43 \\
\hline Oceania & $\begin{array}{c}9.80 \%{ }^{* * *} \\
(9.53) \\
\end{array}$ & 388 & $\begin{array}{c}4.51 \%{ }^{* * *} \\
(8.03)\end{array}$ & 742 & $\begin{array}{c}3.38 \% \\
(7.25)\end{array}$ & 358 \\
\hline \multicolumn{7}{|c|}{ Panel D:Economic development } \\
\hline Developing economies & $\begin{array}{c}3.04 \% \\
(12.21)\end{array}$ & 1294 & $\begin{array}{l}2.92 \% \\
(13.98)\end{array}$ & 2952 & $\begin{array}{l}2.41 \% \\
(8.81)\end{array}$ & 1462 \\
\hline Developed economies & $\begin{array}{c}4.48 \% \\
(18.74) \\
\end{array}$ & 3344 & $\begin{array}{c}2.25 \%^{* * *} \\
(15.96) \\
\end{array}$ & 7042 & $\begin{array}{l}1.73 \%{ }^{* * *} \\
(25.27)\end{array}$ & 8169 \\
\hline \multicolumn{7}{|c|}{ Panel E:Target ownership } \\
\hline Public & $\begin{array}{c}1.88 \% \\
(4.81)\end{array}$ & 565 & $\begin{array}{l}1.30 \% \\
(6.18)\end{array}$ & 1460 & $\begin{array}{l}0.89 \% \\
(6.60)\end{array}$ & 2115 \\
\hline Private & $\begin{array}{l}4.78 \%{ }^{* * *} \\
(16.11)\end{array}$ & 2305 & $\begin{array}{l}3.63 \%^{*} \\
(21.20)\end{array}$ & 4235 & $\begin{array}{l}2.06 \%{ }^{* * *} \\
(20.14)\end{array}$ & 4717 \\
\hline Subsidiary & $\begin{array}{c}3.71 \% \\
(13.65) \\
\end{array}$ & 1768 & $\begin{array}{c}2.97 \% \\
(19.23) \\
\end{array}$ & 3699 & $\begin{array}{c}1.91 \% \\
(16.52)\end{array}$ & 3399 \\
\hline \multicolumn{7}{|c|}{ Panel F: Payment method } \\
\hline Pure cash & $\begin{array}{c}2.56 \%{ }^{* * *} \\
(14.05)\end{array}$ & 2511 & $\begin{array}{c}2.06 \% \\
(19.94)\end{array}$ & 5955 & $\begin{array}{l}1.49 \% \\
(22.81)_{* * * *}^{*}\end{array}$ & 7472 \\
\hline Pure stock & $\begin{array}{l}5.80 \%{ }^{* * *} \\
(12.31)_{* * *}\end{array}$ & 1229 & $\begin{array}{c}4.32 \%^{* * *} \\
(13.63)_{* * *}^{*}\end{array}$ & 1723 & $\begin{array}{c}1.68 \%{ }^{* * *} \\
(7.11)_{* * * *}\end{array}$ & 1262 \\
\hline Hybrid & $\begin{array}{c}5.66 \%{ }^{* * *} \\
(11.50)\end{array}$ & 898 & $\begin{array}{c}4.99 \%{ }^{* * *} \\
(16.73)\end{array}$ & 1716 & $\begin{array}{c}3.23 \%{ }^{* * *} \\
(12.93)\end{array}$ & 1497 \\
\hline
\end{tabular}

This table presents the analysis of 5-day CARs based on different sub-samples. In Panel A, acquisitions are grouped by a one, five, ten, fifteen-year span of observation - in which acquirers completed one, two to four or more acquisitions over one, five, ten, fifteen year(s), and a 19-year span of observation - in which acquirers completed one, two to four or more over the sample span. Percentages in 'All' column are computed by dividing the deal counts for an individual row by the total number of deals. For the rest of the rows, percentages display the proportion of deals in a column category from among those in the row. For Panel D, countries are organized using World Bank classifications. In Panel F, cash offers include cash only and mixtures of cash and debt, stock offers include common stock only or a combination of common stock and options, warrants, or rights, and mixed deals are comprised of some proportion of cash and stock. Relative size is computed as the natural log of target deal value divided by acquirer market value as of one month before the announcement date. $t$-statistics are reported in parentheses. ${ }^{*}, * *, * * *$ represent significance at the $1 \%, 5 \%$ and $10 \%$ level, respectively. 
Table 5. Univariate analysis of cumulative abnormal returns by deal order and temporal interval.

Panel A: Deal order

\begin{tabular}{|c|c|c|c|c|c|c|}
\hline & \multicolumn{2}{|c|}{ Infrequent } & \multicolumn{2}{|c|}{ Frequent } & \multicolumn{2}{|c|}{ Highly Frequent } \\
\hline & CAR $[-2,+2]$ & $N$ & CAR $[-2,+2]$ & $N$ & CAR $[-2,+2]$ & $N$ \\
\hline $1^{\mathrm{st}}$ & $\begin{array}{c}4.02 \% \\
(21.51)\end{array}$ & 4638 & $\begin{array}{c}3.59 \% \\
(19.47)\end{array}$ & 3610 & $\begin{array}{c}3.21 \% \\
(12.32)\end{array}$ & 1252 \\
\hline $2^{\text {nd }}-3^{\text {rd }}$ & & & $\begin{array}{c}2.77 \% \\
(20.95)\end{array}$ & 5213 & $\begin{array}{c}2.20 \%{ }^{* * *} \\
(14.64)\end{array}$ & 2504 \\
\hline$>=4^{\text {th }}$ & & & $\begin{array}{c}1.51 \%{ }^{* * *} \\
(4.83)\end{array}$ & 571 & $\begin{array}{c}1.32 \% \\
(18.34)\end{array}$ & 6475 \\
\hline
\end{tabular}

Panel B: Temporal interval

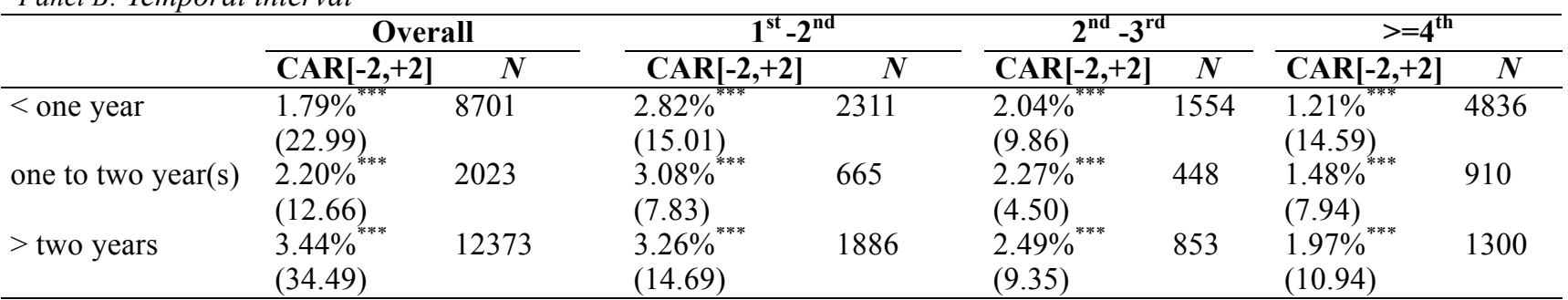

This table presents the analysis of 5-day CARs across deal order. $t$-statistics are reported in parentheses. ${ }^{*}, * *, * *$ represent significance at the $1 \%, 5 \%$ and $10 \%$ level, respectively. 
Table 6. Cross sectional regression analysis of cumulative abnormal returns

\begin{tabular}{|c|c|c|c|c|c|c|}
\hline Dependent variables & $(1)$ & $(2)$ & $(3)$ & $(4)$ & $(5)$ & $(6)$ \\
\hline Private & $\begin{array}{c}0.0166^{* * *} \\
(9.41)\end{array}$ & $\begin{array}{c}0.0101^{* * *} \\
(5.65)\end{array}$ & $\begin{array}{c}0.0101^{* * *} \\
(5.65)\end{array}$ & $\begin{array}{c}0.0173^{* * *} \\
(9.88)\end{array}$ & $\begin{array}{c}0.0102^{* * *} \\
(5.66)\end{array}$ & $\begin{array}{c}0.0099^{* * *} \\
(5.53)\end{array}$ \\
\hline Subsidiary & $\begin{array}{c}0.0153^{* * *} \\
(8.59)\end{array}$ & $\begin{array}{c}0.0112^{* * * *} \\
(6.20)\end{array}$ & $\begin{array}{c}0.0112^{* * *} \\
(6.20)\end{array}$ & $\begin{array}{l}0.0157^{* * *} \\
(8.83)^{* * *}\end{array}$ & $\begin{array}{l}0.0110^{* * *} \\
\quad(6.07)_{* * *}\end{array}$ & $\begin{array}{c}0.0108^{* * *} \\
\quad(6.00)_{* * *}\end{array}$ \\
\hline Cash & $\begin{array}{c}-0.0178^{* * *} \\
(-10.35)\end{array}$ & $\begin{array}{c}-0.0105^{* * *} \\
(-5.32)\end{array}$ & $\begin{array}{c}-0.0105^{* * *} \\
(-5.32)\end{array}$ & $\begin{array}{c}-0.0186^{* * *} \\
(-10.83)\end{array}$ & $\begin{array}{c}-0.0106^{* * *} \\
(-5.37)\end{array}$ & $\begin{array}{c}-0.0105^{* * *} \\
(-5.32)\end{array}$ \\
\hline Hybrid & $\begin{array}{c}-0.0000 \\
(-0.01)\end{array}$ & $\begin{array}{c}0.0024 \\
(1.01)\end{array}$ & $\begin{array}{c}0.0024 \\
(1.01)\end{array}$ & $\begin{array}{c}-0.0010 \\
(-0.50)\end{array}$ & $\begin{array}{c}0.0018 \\
(0.75)\end{array}$ & $\begin{array}{c}0.0018 \\
(0.75)\end{array}$ \\
\hline Cross country & $\begin{array}{c}-0.0002 \\
(-0.15)\end{array}$ & $\begin{array}{c}-0.0020 \\
(-1.38)\end{array}$ & $\begin{array}{c}-0.0020 \\
(-1.37)\end{array}$ & $\begin{array}{c}-0.0000 \\
(-0.02)\end{array}$ & $\begin{array}{c}-0.0018 \\
(-1.25)\end{array}$ & $\begin{array}{c}-0.0017 \\
(-1.20)\end{array}$ \\
\hline Relatedness & $\begin{array}{c}-0.0012 \\
(-0.94)\end{array}$ & $\begin{array}{c}-0.0000 \\
(-0.03)\end{array}$ & $\begin{array}{c}-0.0000 \\
(-0.03)\end{array}$ & $\begin{array}{l}-0.0016 \\
(-1.23)\end{array}$ & $\begin{array}{c}-0.0004 \\
(-0.31)\end{array}$ & $\begin{array}{c}-0.0004 \\
(-0.30)\end{array}$ \\
\hline Relative size & $\begin{array}{c}0.0074^{* * *} \\
(11.41)\end{array}$ & $\begin{array}{c}0.0067^{\text {*** }} \\
(7.52)\end{array}$ & $\begin{array}{c}0.0067^{* * *} \\
(7.52)\end{array}$ & $\begin{array}{c}0.0078^{* * *} \\
(12.23)\end{array}$ & $\begin{array}{c}0.0069^{* * *} \\
(7.65)\end{array}$ & $\begin{array}{c}0.0068^{* * *} \\
(7.64)\end{array}$ \\
\hline Time interval & & $\begin{array}{c}0.0006^{* *} \\
(2.45)\end{array}$ & $\begin{array}{c}0.0006^{*} \\
(1.88)\end{array}$ & & $\begin{array}{c}0.0005^{* *} \\
(2.16)\end{array}$ & $\begin{array}{c}0.0012^{* * *} \\
(3.35)\end{array}$ \\
\hline Frequent & $\begin{array}{c}-0.0074^{* * *} \\
(-4.49)\end{array}$ & & & & & \\
\hline Highly frequent & $\begin{array}{c}-0.0159^{* * *} \\
(-9.00)\end{array}$ & $\begin{array}{c}-0.0071^{* * *} \\
(-5.08)\end{array}$ & $\begin{array}{c}-0.0073^{* * *} \\
(-4.24)\end{array}$ & & & \\
\hline Highly frequent ${ }^{*}$ Time interval & & & $\begin{array}{c}0.0001 \\
(0.18)\end{array}$ & & & \\
\hline No. of deals & & & & $\begin{array}{c}-0.0012^{* * *} \\
(-8.83)\end{array}$ & $\begin{array}{c}-0.0008^{* * *} \\
(-6.71)\end{array}$ & $\begin{array}{c}-0.0007^{* * *} \\
(-5.10)\end{array}$ \\
\hline No. of deals ${ }^{*}$ Time interval & & & & & & $\begin{array}{c}0.0002 \\
(0.57)\end{array}$ \\
\hline Constant & $\begin{array}{c}0.0326 \\
(1.30)\end{array}$ & $\begin{array}{c}0.0250 \\
(0.87)\end{array}$ & $\begin{array}{c}0.0252 \\
(0.88)\end{array}$ & $\begin{array}{l}0.0217 \\
(0.87)\end{array}$ & $\begin{array}{c}0.0190 \\
(0.66)\end{array}$ & $\begin{array}{c}0.0183 \\
(0.64)\end{array}$ \\
\hline Country dummy & $\mathrm{Y}$ & $\mathrm{Y}$ & $\mathrm{Y}$ & $\mathrm{Y}$ & $\mathrm{Y}$ & $\mathrm{Y}$ \\
\hline Industrial dummy & $\mathrm{Y}$ & $\mathrm{Y}$ & $\mathrm{Y}$ & $\mathrm{Y}$ & $\mathrm{Y}$ & $\mathrm{Y}$ \\
\hline Year dummy & $\mathrm{Y}$ & $\mathrm{Y}$ & $\mathrm{Y}$ & Y & Y & $\mathrm{Y}$ \\
\hline Observations & 24263 & 14763 & 14763 & 24263 & 14763 & 14763 \\
\hline$F$-statistic & 11.10 & 6.02 & 5.96 & 11.17 & 6.22 & 6.21 \\
\hline Adjusted $R^{2}$ & $5.09 \%$ & $3.69 \%$ & $3.68 \%$ & $5.06 \%$ & $3.82 \%$ & $3.85 \%$ \\
\hline
\end{tabular}

The table presents ordinary least square regressions of the bidder's 5-day cumulative abnormal returns. Frequent or Highly frequent takes the value one if the acquirer made two to four or more deals over the sample period, respectively. No. of deals is the number of acquisition made by acquirers. Time interval counts number of years between deals. Private and Subsidiary equal to one if the target is a private company or a subsidiary, respectively. Cash and Hybrid indicate if targets are acquired by cash or mix of cash and stock. Cross country and Relatedness take one if acquirer and target come from same geographic region and industry, respectively. Relative size is computed as the natural log of target deal value divided by acquirer market value as of one month before the announcement date. Four-digit SIC code, country and year dummies are included in each model. $t$-statistics are reported in parentheses. $* * *, * * *$ represent significance at the $1 \%, 5 \%$ and $10 \%$ level, respectively. 